\title{
Signs of Decline? Prostheses and the Ageing Subject
}

Hail thou! who liest so snug in this old box;

With sacred awe I bend before thy shrine!

Ob! 't is not clos'd with glue, nor nails, nor locks,

And bence the bliss of viewing thee is mine.

Like my poor aunt, thou haft seen better days!

Well curl'd and powder'd. once it was thy lot

Balls to frequent, and masquerades, and plays,

And panoramas, and the Lord knows what!

Ob! thou hast heard e'en Madam Mara sing,

And oft-times visited my Lord Mayor's treat;

And once, at court, wast notic'd by the King,

Thy form was so commodious, and so neat.

Alas! what art thou now? a mere old mop!

With which our housemaid Nan, who hates a broom,

Dusts all the chamber in my little shop,

Then slyly hides thee in this lumber-room!

Such is the fate of wigs! and mortals too!

After a few more years than thine are past,

The Turk, the Christian, Pagan, and the Jew,

Must all be shut up in a box at last!

Vain man! to talk so loud, and look so big!

How small's the difference 'twixt thee and a wig!

How small indeed! for speak the truth I must,

Wigs turn to dusters, and man turns to dust.

(C) The Author(s) 2022

R. Sweet, Prosthetic Body Parts in Nineteenth-Century Literature and Culture, Palgrave Studies in Nineteenth-Century Writing and Culture, https://doi.org/10.1007/978-3-030-78589-5_6 
— "Modern Sonnet. To an Old Wig," in The Spirit of the Public Journals for 1802, vol. 6 (London: James Ridgway, 1803).

This poem, which appeared numerous times in the nineteenth-century periodical press, provides an apt starting point for a chapter about prosthesis use and ageing. ${ }^{1}$ Published first in 1802, these verses dedicated "To an Old Wig" put forward several themes that would be developed and drawn upon repeatedly in depictions of elderly prosthesis users over the course of the century. Such topics include the elision of age and prosthesis use, the revulsion to vanity and falsehood, and the tension between the natural and the artificial. The poem equates the aged with redundancy, an association that would be buttressed by many writings in the years that followed. Although we see the prostheses of the elderly depicted as somewhat useless devices in many other depictions, here an old wig has more use (and longevity) than an elderly person. While man "turns to dust," wigs "turn to dusters." Old wigs, these stanzas suggest, retain at least a degree of purpose and functionality, while elderly people are treated as detritus.

Although, as Pat Thane observes, in the nineteenth century "people aged over sixty were a smaller proportion of the population than for several centuries," a significant share of the prosthesis users that we see depicted in nineteenth-century fictional and cultural works are elderly. ${ }^{2}$ There are several famous examples: Brigadier General John A. B. C. Smith from Edgar Allan Poe's “The Man That Was Used Up” (1839), Captain Cuttle and Mrs. Skewton in Charles Dickens's Dombey and Son (1846-1848), and Mr. Bashwood and Mrs. Milroy in Wilkie Collins's Armadale (1864-1866). ${ }^{3}$ From these select works alone, we see a range of users, including elderly spinsters, ageing aesthetes, and maimed war veterans. These individuals use a variety of devices, from wigs, false teeth, and makeup to artificial legs, hook hands, and even mechanical palates. Despite their differences, all of these characters are bound by plots that centre on decline, deception, and discrepancy (between old and young, and between artificial and organic).

While attempts to resist senescence today are often applauded, during the nineteenth century, the use of prostheses by those experiencing physical decline in order to hide signs of ageing was regularly lambasted as an act of vanity or, worse, fraudulence. Though these attitudes were commonplace in the literature of this period, ageing prosthesis users and artificial body parts themselves performed a variety of roles in fictional works, 
functioning interchangeably as comic motifs, as signifiers for a variety of character traits-including vanity, duplicitousness, and credulousnessand as synecdoches for a broader social system that privileged youth and physical wholeness. Many imaginaries satirized this social privileging, showing how it led to preposterous results. As I show here, the association of ageing and prosthesis use was so strong that even those who might not be considered elderly in terms of years lived were depicted as aged or past their best because of their use of a prosthetic device. As we might expect, primarily cosmetic prostheses, including wigs, false teeth, and artificial eyes, became synonymous with representations of ageing.

\section{Attitudes to Ageing}

To consider first some facts and figures, George R. Boyer and Timothy P. Schmidle's study "Poverty among the Elderly in Late Victorian England" shows us that in 1861 "there were 932,000 persons aged 65 and over in England and Wales, representing 4.6 per cent of the population. By 1891, there were nearly 1.4 million persons aged 65 and over in England and Wales, or 4.7 per cent of the population." 4 As Anne-Julia Zwierlein, Katharina Boehm, and Anna Farkas suggest in the introduction to their important collection Interdisciplinary Perspectives on Aging in Nineteenth-Century Culture, "the percentage of older people among the population was less pronounced during the nineteenth century." However, as they show, numerous factors contributed to what they describe as "an unprecedented level of cultural attention on the experience of aging and old age." ${ }^{5}$ Zwierlein, Boehm, and Farkas point to factors such as the expanding market for print publications, social reform movements that laid the groundwork for the emergence of the welfare state, and the growth of new scientific and medical modes of inquiry (including gerontology). Karen Chase argues similarly that cultural attention to the elderly reached a peak at the end of the nineteenth century. ${ }^{6}$

The elderly certainly came to cultural prominence in the Victorian period but it is harder to pinpoint exactly what the prevailing attitudes to old age were. As Thane explains: "In all times there have been competing optimistic and pessimistic paradigms of old age and we cannot readily determine whether one or the other was culturally dominant. All cultures have a variety of images of ageing available to them from which individuals and groups shape their expectations. These images shift and compete and if any one of them gains hegemony it does not necessarily do so for long."7 
As Chase shows us, attitudes to ageing were split by several tensions. First, the continuing resonance of the Ciceronian ideal of old age as a period of dignity, serenity, wisdom, respect, and self-respect contrasted growing examples of old age as misery, bewilderment, loneliness, and disentitlement. Second, the spreading deprivation of the aged at the bottom of the social ladder opposed the power of ageing figures including Queen Victoria, William Ewart Gladstone, and Benjamin Disraeli. Third, crossgenerational relationships were a preoccupation of imaginative life while generational fractures also became apparent, especially when partisans of the New contested the iconography of the old-in particular at the moment of the Queen's Jubilees and in the retrospection of the fin de siècle. ${ }^{8}$ While this chapter resists a monolithic view of ageing in the nineteenth century, many literary responses to the prostheses of the elderly cast a negative light on both the aged and the means of artifice that they used to mask their perceived bodily losses. Such responses, however, ironically often attacked the very devices brought to life by privileging youth and wholeness.

The nineteenth-century prosthesis market itself drew together concepts of ageing and physical loss in its advertising rhetoric. Cashing in on the insecurities of those showing signs of physical decline, contemporary prosthesis makers marketed their devices towards those wishing to disguise losses resulting from senescence. An advertisement for Mr. Scott, Surgeon and Mechanical Dentist, published in Bell's Life in London and Sporting Chronicle in 1830, for instance, began, "IMPORTANT to all desirous of Perfection, Comfort and Economy." In the advertisement section of a single 1858 copy of Lady's Magazine, a periodical written for well-to-do mature women, two adverts for false teeth appear next to adverts for hair dye, hair serum, and a baldness cure. ${ }^{10}$ An 1867 Bell's Life in London and Sporting Chronicle advertisement for Messrs. Mosley's "Teeth and Painless Dentistry" assured potential customers, many of whom we assume were middle aged or older, that "artificial teeth (from one to a complete set) can be inserted with so exact a semblance to nature that detection is impossible, the original proportions of the face and mouth being restored to their pristine perfection" (emphasis added). ${ }^{11}$ Significant here is the promise to restore "pristine perfection," which aligns youth with wholeness and therefore perfection. Intriguingly, cultural depictions of users of false teeth and other prostheses tended not to agree with the bold promises of advertisements. The obviously false and thus abhorrent prosthesis 
became a popular shorthand for the ageing subject across a range of literary and cultural sources.

Curiously, it was not only devices that we might call primarily cosmetic prostheses, such as wigs and dentures, which became insignias for old age in this period; peg legs, rather than their more expensive and sophisticated counterparts, artificial legs (see Chap. 4), were also often associated with old age. This association stemmed in part from the proliferation of images of prosthesis-using Greenwich and Chelsea pensioners (see Figs. 6.1 and 6.2 ), and other maimed war veterans, who were sometimes represented as decrepit street beggars (see Figs. 4.1 and 4.2) ${ }^{12}$ Due to the kind of amputation procedures performed on many maimed military men and the relatively basic provisions provided by the state, as well as the perpetuation of attitudes that saw disability as a sign of unfitness for work, British veterans

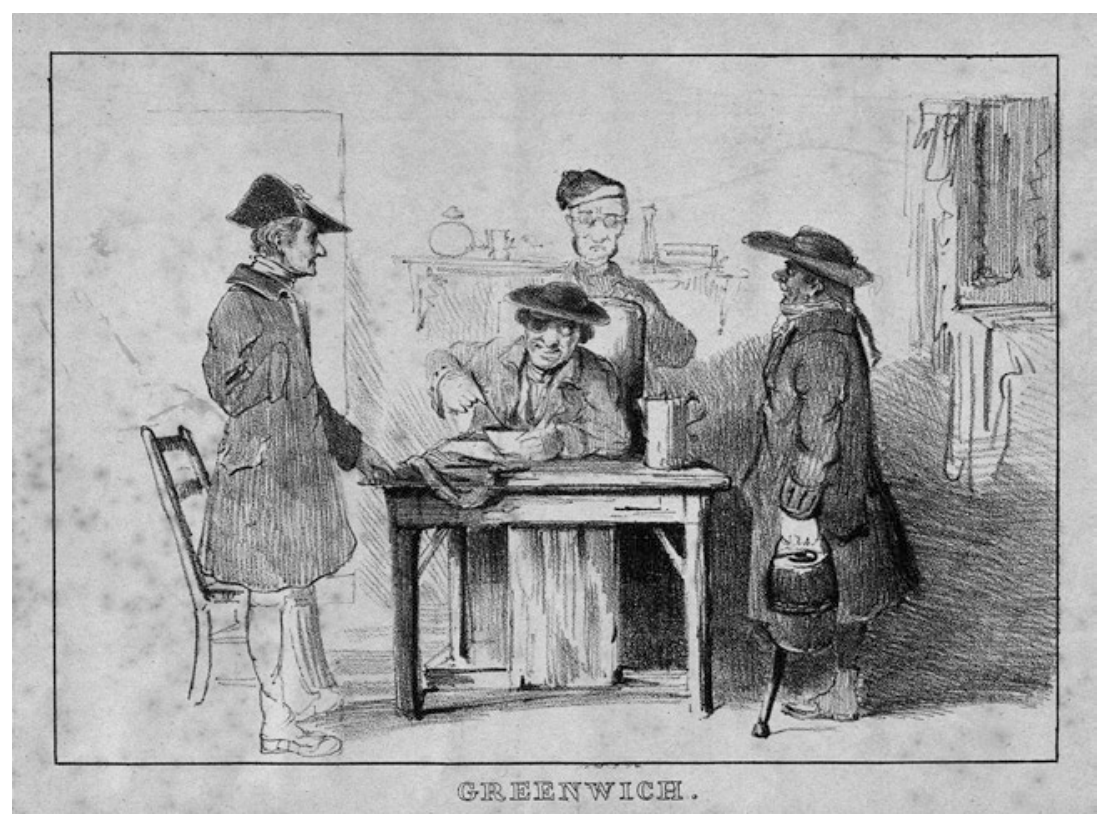

Fig. 6.1 A lithograph depicting four Greenwich pensioners congregating around a table. The pensioner on the left is an arm amputee and the figure to the right uses a pin-design prosthetic leg. Greenwich, n.d., lithograph, $14 \times 19.7 \mathrm{~cm}$, Wellcome Trust, London. Image courtesy of the Wellcome Collection. https://wellcomecollection.org/works/cr2enpd4. CC BY 4.0 


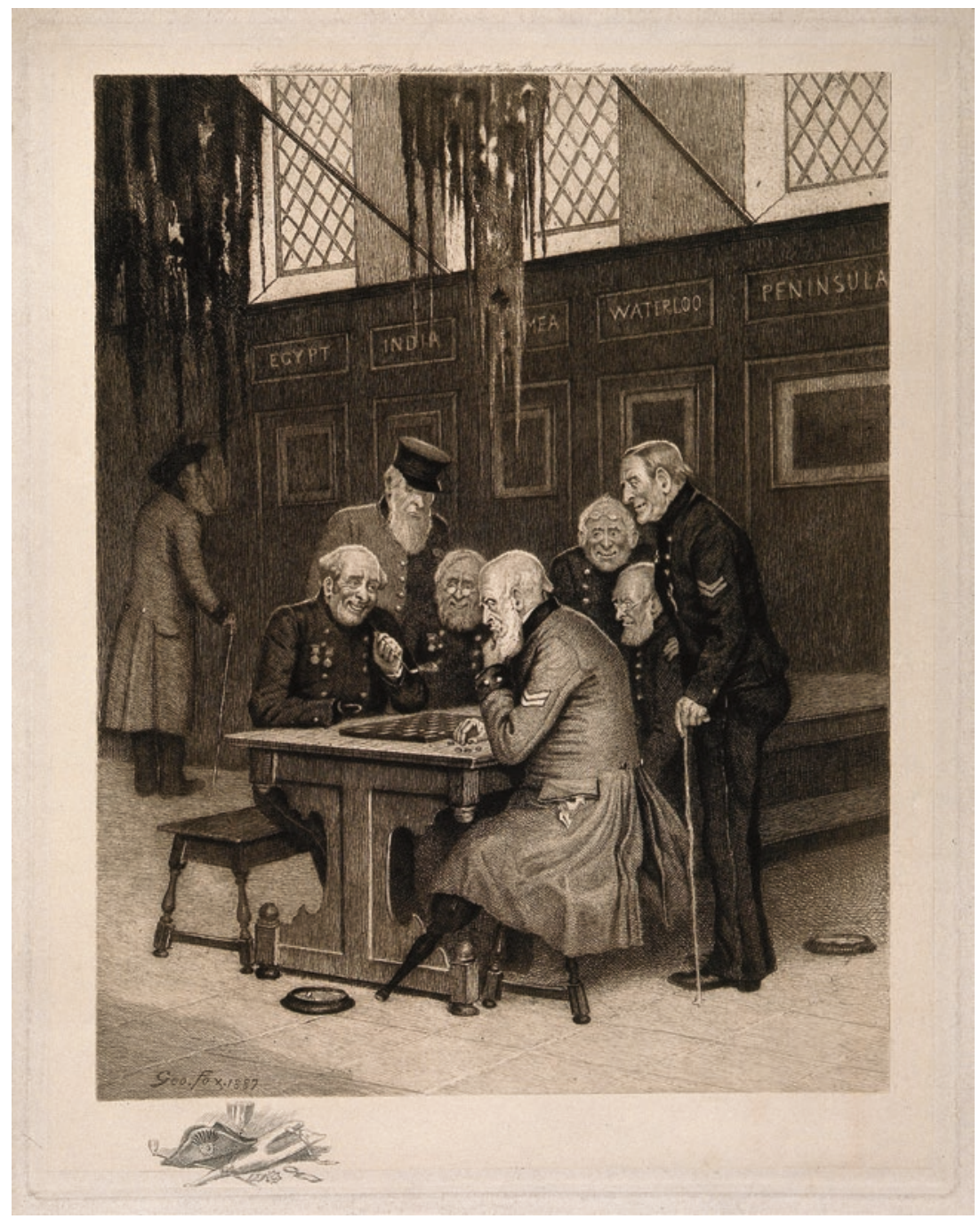

Fig. 6.2 A late nineteenth-century etching of Chelsea pensioners playing draughts. The figure in the foreground is seated, with his wooden leg protruding to the side of the table. George Fox, "A pair of Pensioners," seated at a table, playing draughts, with others looking on, inside the Royal Hospital, Chelsea, with a vignette of tricorn hat, wooden leg, clay pipe, drinking glass and medals at lower left, 1887, etching, $30.5 \times 23.8 \mathrm{~cm}$, Wellcome Collection, London. Image courtesy of the Wellcome Collection. https://wellcomecollection.org/works/ sacuezvv. CC BY 4.0 
tended to be jobless after sustaining their injuries, reducing them to a state similar to that of elderly men, who were also often excluded from the workplace. ${ }^{13}$ Legislation such as the Poor Law Amendment Act 1834 reinforced associations of the elderly and the disabled, since this legislation exempted from the workhouse unemployed subjects from both groups. In terms of masculinity, then, infirmity caused by impairment and infirmity caused by old age were conceptually linked in as much that both states were believed to represent an inability to work. For women, by comparison, the use of false limbs had a similar ageing effect since attitudes towards conspicuous physical incompleteness excluded them from the marriage market, aligning them conceptually with so-called spinsters.

Given that the perceived absurdity of prosthesis use is a focus of my analysis, it is perhaps unsurprising that humour is a prevalent aspect of the sources under discussion. This chapter understands humour primarily by way of incongruity theory, the current pre-eminent approach in humour studies. As John Morreall explains, "What makes ... situation[s] ... humorous, according to the Incongruity Theory, is that there is something odd, abnormal or out of place, which we enjoy in some way. In its simplest form, the theory says that humorous amusement is the enjoyment of incongruity." 14 Foundational humour studies writer Stephen Leacock sees Victorian humour as emblematic of this theory: "[it] finds its basis in the incongruity of life itself, the contrast between the fretting cares and the petty sorrows of the day and the long mystery of tomorrow." $15 \mathrm{My}$ discussion bears in mind the compatibility of the incongruity theory of humour with Mitchell and Snyder's theory "narrative prosthesis," a comity exposed by Tom Coogan and Rebecca Mallet. ${ }^{16}$ Underlining the overlap in these approaches, Coogan and Mallet write: "[n]arrative prosthesis identifies disability as the crutch upon which narratives lean for their representational power; incongruity theory, as Morreall explains, attributes humour to situations where 'there is something odd, abnormal or out of place, which we enjoy in some way." "17 What both theories have in common, then, is a notion that the strategic placement of the non-normative is a key component of affect.

In the sources that I examine here, the prostheticized body or prosthetic part is the incongruity at the comic centre, a perceived oddness that is emphasized by the age of the subject. The use of a prosthetic device is sometimes revealed suddenly in an unveiling scene that uses a period of suspense beforehand to heighten comic release-providing further evidence for the compatibility of incongruity and relief models of humour. ${ }^{18}$ 
In these instances, the unveiling scene often occurs at a moment or in a specific setting that exacerbates the incongruousness of the prosthesis and therefore the embarrassment of the user. Elsewhere, the prosthetic body part is centred relatively early and it is the incongruousness of it, as signalled by the extent to which it stands out-because it looks unreal, does not suit the appearance of the user, or is being used in a non-normative way-that draws readers' laughs. Another comic trope draws humour from the incongruousness of a non-prosthesis user's inability to distinguish the artificial from the real, a distinction that is apparently blatant to everyone else, including the reader. In disability-studies terms, one might argue that each representational type draws attention to "a pattern of cultural representation which always maintains physically different people as other, as alien, as the object of curiosity or hostility or pity, rather than as part of the group." 19 However, behind the ableist and ageist veneer of comical representations of ageing prosthesis users was often a critique of the privileging of the young and whole body, physical states that appear both ephemeral and unstable. These depictions draw our attention to the ludicrous situations and displays that cultural pressures to maintain normative standards give rise to.

The following analysis traces the trope of the ageing prosthesis user from the 1830s through to the fin de siècle. I begin by investigating Poe's representations of grotesque artificially constructed elderly subjects, portrayals that drew from the harsh humour of eighteenth- and early nineteenth-century caricature and satire, redirecting laughs towards those unable to perceive the difference between the artificial and the organic. I then go on to show how ageing prosthesis users were reconceptualized in sensation fiction, a genre that borrowed much from the Gothic mode that underpinned Poe's fiction. In Wilkie Collins's narratives, wigs are used simultaneously as light comic props, which at surface value further stigmatize the elderly and physically incomplete, and synecdoches through which wider social structures are critiqued. Meanwhile, in the late nineteenthcentury periodical press the trope of the ageing prosthesis user had become a popular culture icon, one that was less vulgar than earlier deployments but still critical of the absurdities that social pressures to conform to hegemonic norms could bring about. Finally, I explore several late-century imperial adventure fictions, a genre that utilized the prevalent prosthetic motif. Revealing an increased consciousness of age anxiety, imperial adventure tales continued to laugh at ageing prosthesis consumers by transgressively turning preferences for wholeness on their head. 


\section{VANity AND CALAmity}

Images of the elderly undressing and removing their prostheses have a long history. There were popular humorous tropes during the "golden age of caricature," which extended from the 1760s through to the 1820s, a period in which artists such as James Gillray, Thomas Rowlandson, and George Cruikshank achieved notable success. ${ }^{20}$ In P. Roberts's 1807 coloured etching after G. M. Woodward, Celia Retiring, a bald, toothless, and overall dishevelled-looking elderly woman gives precise instructions to her servant about laying out her wig, false bosom, dentures, and false eyebrows so that she can get ready to meet "[her] Lord Ban" in good time the next day (Fig. 6.3). Similarly, F. S. Delpech's 1825 coloured lithograph after L. L. Boilly, Les époux assortis, displays an elderly couple removing their various prostheses-wigs, sets of false teeth, and a glass eye (Fig. 6.4). An even earlier but remarkably similar literary example of such a scene is described in detail in Jonathan Swift's infamous satirical poem "A Beautiful Young Nymph Going to Bed" (1731). ${ }^{21}$ Dickie shows us that this period was remarkably spiteful towards those seen as physically aberrant. The body, in its most unsightly, vulnerable, and non-normative forms, was, as Dickie argues, a central theme in eighteenth-century humour despite the period's demure pretensions. ${ }^{22}$ In Boilly, Woodward, and Swift, the ageing body is exposed as frail and abhorrent without prostheses. The prostheses themselves are simultaneously uncanny, deceitful, and concealing devices, which align with a grotesque aesthetic. The elderly are unceremoniously mocked while the culture of artifice is lambasted.

Though by no means a Victorian invention, the trope of the elderly person with prostheses extended and perpetuated from the 1830s onwards. Chase shows how the theme of ageing became increasingly central in the social consciousness as the nineteenth century progressed. As Chase suggests, a constellation of events brought about "the ripening consciousness of age," which she calls "the invention of the elderly subject." 23 These factors include the legislative movement towards the Old Age Pensions Act 1908; the ageing and then the death of the Queen Victoria; the "ethological" investigations conducted by Charles Booth; the emergence of gerontology as a medical sub-discipline; the increasing perception of a generational divide; and the proliferating images of ageing bodies. The increase in cultural representations of the elderly with prosthetics maps roughly onto Chase's trajectory, which traces the ways in which the elderly become a mainstream concern at the fin de siècle. We can add four 


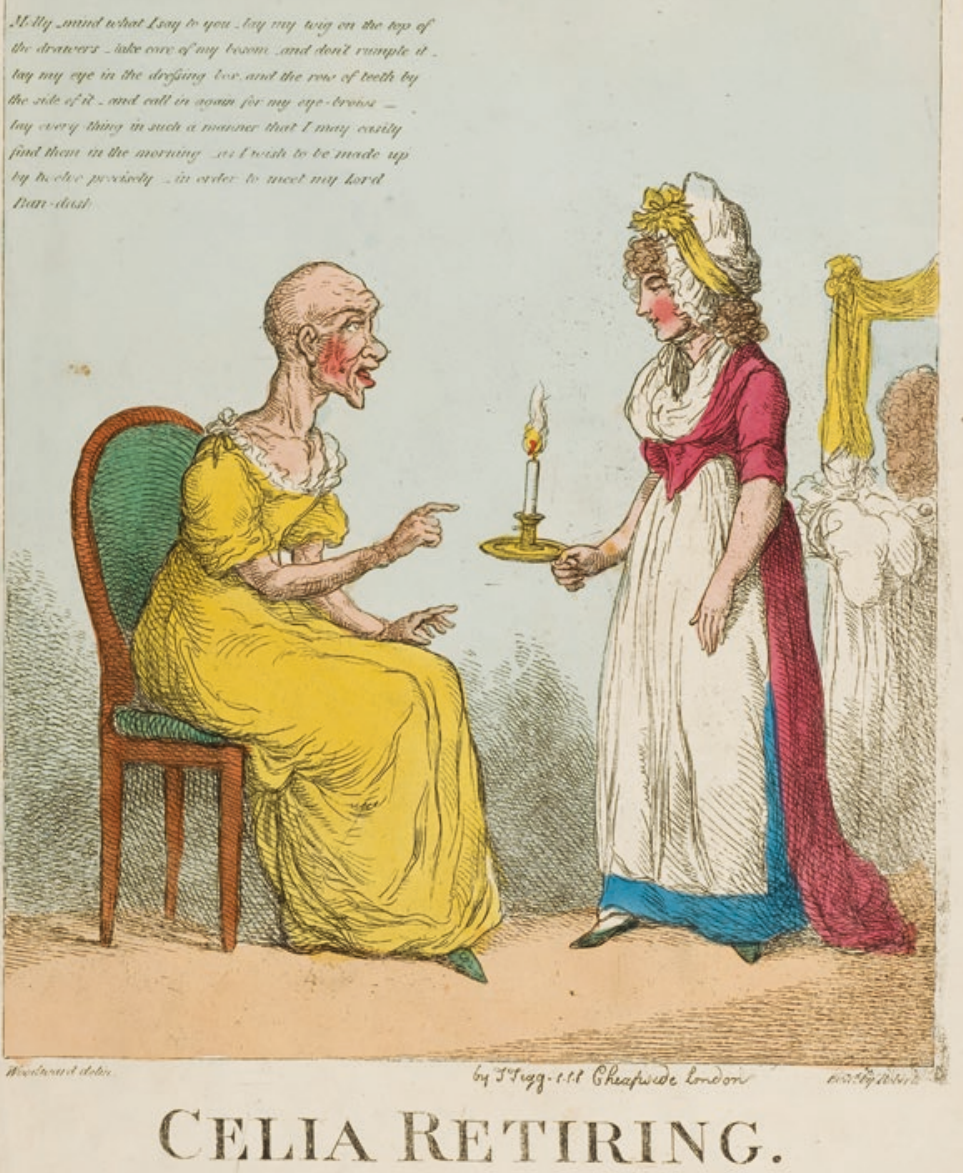

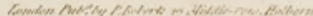

Fig. 6.3 A coloured etching depicting an elderly lady providing strict instructions to her servant regarding her prostheses. She says, "Molly, mind what I say to you. Lay my wig on the top of the drawers. Take care of my bosom and don't rumple it. Lay my eye in the dressing box, and the row of teeth by the side of it. And call in again for my eyebrows. Lay everything in such a manner that I may easily find them in the morning, as I wish to be made up by 12 precisely, in order to meet my Lord Bandash.” P. Roberts after G. M. Woodward, Celia Retiring, c. 1807, etching with watercolour, $35 \times 26.5 \mathrm{~cm}$, Wellcome Collection, London. Image courtesy of the Wellcome Collection. https://wellcomecollection.org/works/m4kdj55c. CC BY 4.0 


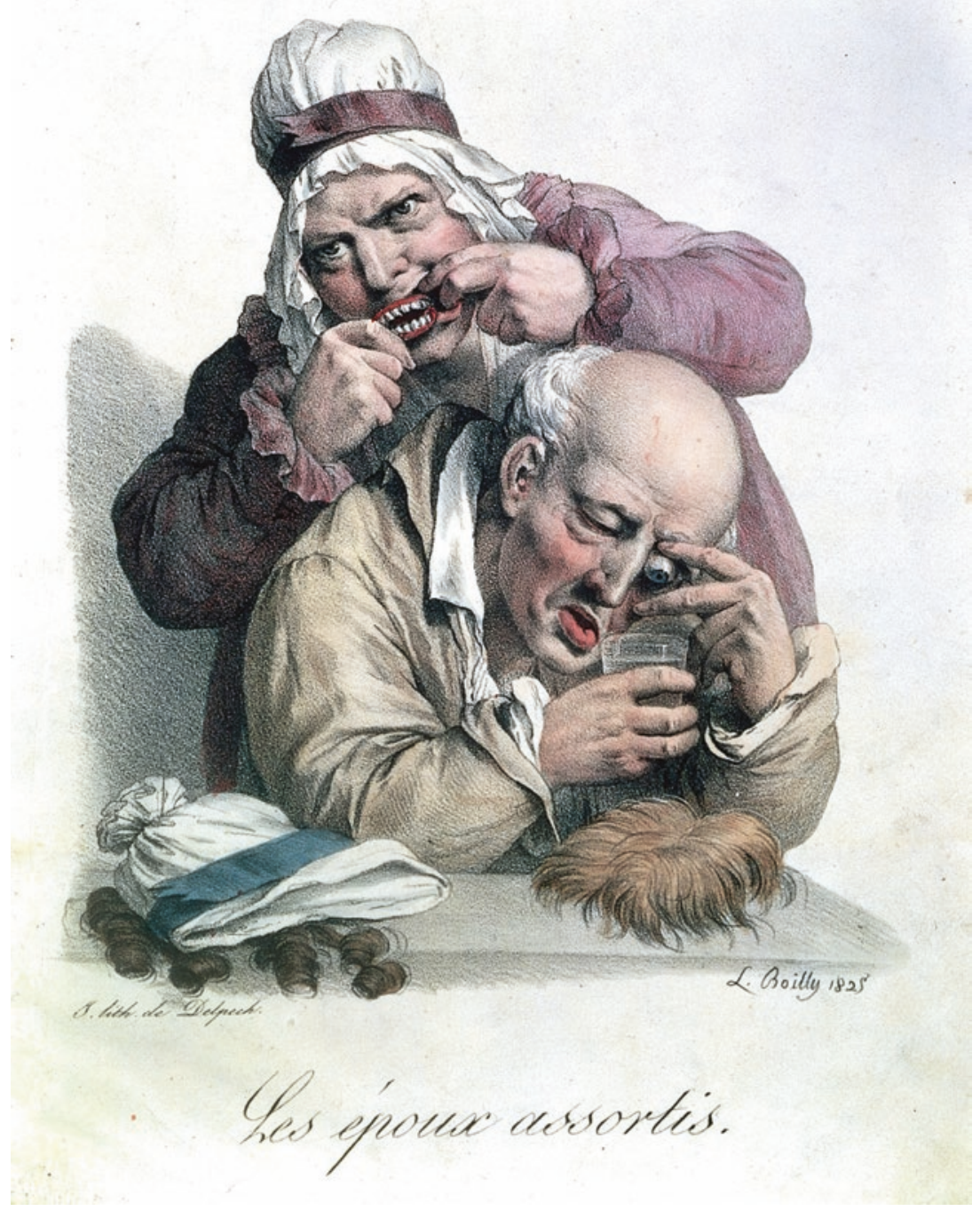

Fig. 6.4 A coloured lithograph portraying an elderly couple removing their prostheses - wigs, eyes, and teeth. F. S. Delpech after Louis Leopold Boilly, Les epoux assortis, 1825, lithograph with watercolour, Wellcome Collection, London. Image courtesy of the Wellcome Collection. https://wellcomecollection.org/ works/f8p4baxv. CC BY 4.0 
additional factors to Chase's comprehensive list. First, Britain witnessed the entering into old age of its amputee veterans of the Napoleonic wars and a continued cultural presence of war veterans, including Greenwich and Chelsea pensioners. Second, the 1850s American invention of sulphurhardened rubber, Vulcanite, which became the most popular material for manufacturing the bases of dentures, inaugurated "the era of false teeth for the masses." ${ }^{24}$ Third, wig-wearing took off in the 1860s and 1870s as women sought to emphasize "their femininity through masquerade." 25 Finally, in ironic contrast to the previous two contexts, post-Regency puritanism extended into the nineteenth century, labelling the use of artifice a vanity. $^{26}$

Poe provides a couple of examples of grotesque elderly characters, which evoke those depicted in the earlier works of Woodward, Boilly, and Swift. Both "The Man That Was Used Up" and "The Spectacles" (1844) depict aged characters whose bodies are substantially supplemented by prostheses. $^{27}$ Like Swift's "Young Nymph," the artificiality of the prosthesis-using characters described in Poe's stories is revealed in undressing scenes of sorts. In "The Man that Was Used up," Brevet Brigadier General John A. B. C. Smith, a retired and venerated war veteran, appears mysterious to the tale's curious narrator until the latter witnesses him getting dressed one morning. The veteran is as much an assemblage of many components as his excessively long name: several of his body parts are prosthetic, including a leg, an arm, both shoulders, his bosom, his hair, his teeth, an eye, and his palate. Despite his extreme dependence on prostheses, Smith is earlier described as striking in appearance: "There was an air distingué pervading the whole man, which spoke of high breeding, and hinted at high birth." 28 Likewise, in "The Spectacles" Madame Eugénie Lalande is presented as an enticingly beautiful physical specimen. Moreover, like Smith, she turns out to be the user of many prostheses. Eugénie's "perfect fullness and tournure" turns out to be the work of a "false tournure"; her "beautiful black hair," the work of a wig; and her "pearly teeth," the work of dentures. ${ }^{29}$ These devices allow Eugénie to trick the narrator, Simpson, who it is revealed is the attractive woman's great-great-grandson. Eugénie agrees to marry Simpson to teach him a lesson about the importance of vision as a physiognomic tool of selection. Her rather heavy-handed moral is that Simpson should wear spectacles to make up for his poor eyesight. As in "The Man that Was Used up," the ability of prostheses to mimic a younger, natural physical appearance provides the elderly user with a specific kind of technologically enabled agency. 
One could argue that "The Spectacles" is a story all about the importance of keeping up-to-date with technologies that enhance or supplement the body, since the titular assistive aid ultimately makes Simpson better off-at the very least less prone to making erroneous misreadings about those around him.

These imaginaries, which can both be read as reworkings of the mistaking-artifice-for-reality narrative "The Sandman" by E. T. A. Hoffmann (1817), reveal anxieties about the increasing dominance of technology mixed with distrust towards deceitful ageing subjects who rely on prostheses to attain a youthful aesthetic. ${ }^{30}$ These stories poke fun at society's reliance on bodily technologies while problematizing the social pressure to use such devices. The practice of prostheticizing the body is displayed as grotesque by the dismantling and rebuilding scenes of both works while those unable to recognize artifice are mocked for their ignorance. As much as Madame Lalande's and Smith's respective prostheses are shown to be curiously incongruous when they are detached, physiognomic adjustment is shown to be needed in a world where appearances can be misleading. Relating to nineteenth-century physiognomy and visual modes of judging today, Sherrona Pearl has shown us that "[w]hat one sees in others tells a great deal about oneself." 31 The humour in these stories stems in part from what we learn about the narrator through his physiognomic judgements: that he is dangerously (but also hilariously) unperceptive. Critically, however, in both stories the privileging of youth and wholeness is shown to be self-defeating since the pressure that it produces leads the elderly and physically incomplete to prostheticize their bodies, thereby duping the normate into believing that incomplete bodies are actually physically whole. In these specific cases, the ability of the prosthesis to enhance the appearance of the subject complicates the hegemony of normalcy, since the false takes precedence over the organic: prostheses achieve a better-than-real aesthetic for Poe's cyborgian elderly subjects, thus confounding the subject group who are supposed to be dominant. The normate becomes a victim of his own prejudices.

\section{False Part, Flawed Whole}

Drawing from the Gothic, sensation fiction is another genre that offers much to the discussion of bodies, ageing, and artifice in the Victorian period. The human body is central to the narrative structure and affective force of sensation fiction. As Martha Stoddard Holmes and Mark Mossman 
write: "Sensation fiction's relationship to embodiment has been overdetermined from the start, given that its poetics, its plotting and characterization, and its critical reception have used the body as a nexus of expression, experience, and meaning-making." 32 The portrayals that I discuss here comically mock vain, ageing users of artifice while subtly delivering a double assault on both social pressures to conform to normate physical standards and the linked matrimonial preferences for good looks and wealth that such a society propagated.

In his novels Armadale (1864-1866), The Law and the Lady (1875), and The Black Robe (1881), the sensation novelist Wilkie Collins depicts a variety of ageing male and female characters who the author mocks for their vanity. ${ }^{33}$ Lisa Niles makes a convincing argument about the way that cosmetics are deployed in Collins's Armadale as a false concern that draws the reader's attention to what she identifies as the real threat, embodied by Lydia Gwilt: a criminal, ageing body that successfully passes as a younger body in a marriage market that relies on age being clearly demarcated. According to Niles, "Collins challenges the terms upon which society constructs a middle-class, marriageable female identity." 34 Collins's critique of Victorian's society's paradoxical engagement with ageing, however, is not restricted to women. As Collins suggests through his depictions of unmarried ageing male characters - such as Bashwood from Armadale and Major Fitz David from The Law and the Lady-single ageing (usually middleclass) men could also feel the brunt of social prejudices against incomplete bodies, inclining them to use artificial adornments. Nonetheless, Collins's attitude to prosthesis-using ageing men is far from sympathetic. His fictions critique both the culture that encourages ageing men (and women) to use cosmetic aids (including artificial body parts) to look younger and fuller, and the men whom he sees as foolish enough to give into the weight of societal pressures. Both Armadale and The Law and the Lady underline what Collins saw as the futility of male vanity by suggesting that physical appearances are not as important for men as they might think; in these narratives, wealth is critically exposed as the fundamental, though problematic, criterion for women when choosing their partners. Collins thus displays consternation towards two related social systems: first, that which pressures ageing men to use cosmetic adornments, thereby in his eyes making themselves look ridiculous; and second, the marriage system in which appearances and wealth are privileged over deeper personal qualities.

Collins's novels depict conventional responses to artifice as a means of disguising senescence. His two female characters who conspicuously use 
prostheses are Mrs. Milroy from Armadale and Miss Notman from The Black Robe. Mrs. Milroy, the paranoiac and invalid mother of Miss Neelie Milroy (the eventual wife of the protagonist Allan Armadale), is discussed at some length by Niles. She considers by the wig- and rouge-wearing Mrs. Milroy a character who reaffirms prejudices against elderly women attempting to defy the process of ageing. ${ }^{35}$ To put this assertion into context, Lola Montez, Countess von Landsfeld, advised in 1858 that "in no case can even rouge be used by ladies who have passed the age of life when roses are natural to the cheek. A rouged old woman is a horrible sight-a distortion of nature's harmony!" 36 Niles, however, contends that Mrs. Milroy "provides readers with a false sense of surety in the ability to detect artifice, as her self-presentation appears to reduce the threat of cosmetics from something fearful to something ridiculous." ${ }^{37}$

While Mrs. Milroy is both married and impaired by illness, which makes her vanity (in Victorian terms) even more preposterous, Miss Notman from The Black Robe is single but also presented as absurd for using a wig-in this case, especially, it would appear, because of her lowly status as a housekeeper. The narrator's first significant description of Notman reveals that her use of a wig is a translucent insignia of her flawed character:

When Miss Notman assumed the post of housekeeper in Lady Loring's service, she was accurately described as "a competent and respectable person;" and was praised, with perfect truth, for her incorruptible devotion to the interests of her employers. On its weaker side, her character was represented by the wearing of a youthful wig, and the erroneous conviction that she still possessed a fine figure. The ruling idea in her narrow little mind was the idea of her own dignity. Any offence offered in this direction oppressed her memory for days together, and found its way outwards in speech to any human being whose attention she could secure. ${ }^{38}$

The syndetic pairing of wearing "a youthful wig" and "the erroneous conviction that she still possessed a fine figure" puts her very much in the same boat as vain, ageing prosthesis-using women depicted elsewhere in Victorian fiction, including Lady Maria Esmond from Thackeray's Virginians (1857-1859), Mrs. Skewton from Dickens's Dombey and Son, and Lady Carbury from Anthony Trollope's The Way We Live Now (1875). ${ }^{39}$ However, unlike Lady Maria, Mrs. Skewton, Lady Carbury, or even Mrs. Milroy, Miss Notman is of a lower social station, making her vanity seem redundant. Whereas upper-class and middling female 
characters, including Lady Maria, Lady Carbury, and Mrs. Skewton, face increased public scrutiny in their respective imaginative universes as respectable women of polite society, thereby pressuring them to attempt to look more youthful, Miss Notman's work confines her to domestic spaces, thereby necessitating a neat and tidy but not showy appearance. To a contemporary readership, her supposed vanity thus exposes her as someone with ideas above her station. This trait combined with the view that she is elderly makes her an object of ridicule. ${ }^{40}$

Miss Notman's "youthful wig" to her matches what she believes is a "fine" youthful figure. This stance positions her among the many who tried (and often failed) to disguise visible signs of ageing, believing that looking younger would bring rewards. Unfortunately for Miss Notman, she is not Lydia Gwilt - a character able to disguise her true age. Notman's attempt to look youthful is mocked by Collins, who takes a stance not too dissimilar to Margaret Morganroth Gullette, whose work problematizes the logic of "performing" youth through cosmetic surgery in the twentyfirst century:

The men and women who get facelifts or liposuction ... try on a crude appliance to pass for "younger" to stereotyped eyes. Whatever else is wrong with this, it's like stuffing in falsies or a pair of socks to represent gender. It's both bad acting and a misreading of culture. They are treating "age"- - or in this case "youth" - as a wholly separable identity. Obliterating a few of the obvious signals that everyone knows comes solely from the age code, like "wrinkles" or "love handles," they try to forget that in our culture the hypercritical age gaze notices all the more obsessively their other decline-linked signals. ${ }^{41}$

For Collins, Notman's “youthful wig" is also a result of "bad acting” and "a misreading of culture." Her wig is conspicuous: through a contrast to her otherwise ageing appearance, it draws attention to her as an imposter. She misreads her culture not only by thinking that people will be duped by her ploy but also by presuming that it is necessary for her to maintain an appearance of youth in the first place. However, when one considers the overwhelming social pressure that encouraged women to display youthful and physically whole appearances, we begin both to empathize with Miss Notman and to see Collins's deeper critique of social pressures regarding physical presentation.

The most poignant aspect of Collins's depiction of Miss Notman is the way that her youthful wig is used as a symbol of her weaknesses. Notman 
is revealed to be both frivolous and pompous by her actions: she unwittingly reveals information to the novel's villain, Father Benwell, that allows him to conspire against Collins's protagonist. She also almost quits her position after feeling that her dignity is affronted following a disagreement regarding whether to serve an oyster omelette before or after pudding. The early conviction that "her character was represented by the wearing of a youthful wig, and the erroneous conviction that she still possessed a fine figure" thus stands true ${ }^{42}$ Collins's past-their-best female prosthesis users seem to provide historical evidence for Susan Sontag's "double standard" of ageing. ${ }^{43}$ These depictions suggest that in the high-Victorian period, some ageing women felt the need to look younger, even when in social positions where it might seem unnecessary.

Collins's critique of prosthesis users for attempting to pass as youthful, however, extended beyond women. Through his depiction of foolish, ageing men, Collins associated the problem that he saw not with a specific gender but with the social system more broadly. Major Fitz David from The Law and the Lady is another comic character, though his eventual fate exposes the sorry results of an ageing aesthete's use of cosmetics. When the novel's protagonist and narrator, Valeria Woodville, an attractive but intelligent and driven young woman, first approaches the Major for help uncovering the mystery behind her husband's decision to conceal his true surname (Macallan), the Major is described in flamboyant terms:

[A] well-preserved old gentleman of, say, sixty years old, little and lean, and chiefly remarkable by the extraordinary length of his nose. After this feature, I noticed next his beautiful brown wig; his sparkling little gray eyes; his rosy complexion; his short military whisker, dyed to match his wig; his white teeth and his winning smile; his smart blue frock-coat, with a camellia in the button-hole; and his splendid ring, a ruby, flashing on his little finger as he courteously signed to me to take a chair. ${ }^{44}$

A little later, we learn that the Major's eyebrows are also "dyed to match his whiskers." ${ }^{45}$ Fitz David's impressively made-up, pristine appearance is concomitant with his youthful, showy persona. At one point, the Major is described as "speaking in the character of a youth of five-and-twenty." 46

In addition to his faux-young appearance, he also has a taste for women somewhat younger than he is. One of his admirers, the girl whom he eventually marries, is described by Valeria as "a plump, round-eyed overdressed girl, with a florid complexion and straw colored hair." ${ }^{47}$ Valeria herself is 
described as "young" by the Major's servant, Oliver, priming the former for his first encounter with Collins's heroine:

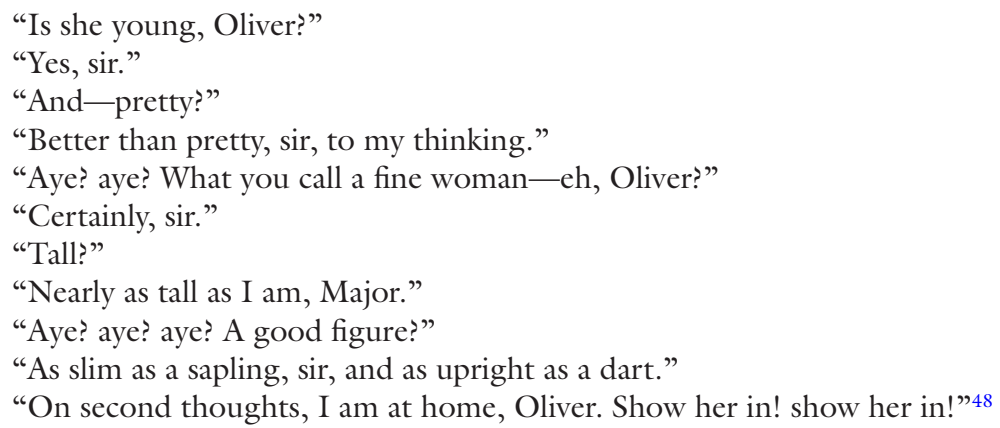

Here and elsewhere, the Major's weakness for women, a characteristic usually associated with younger men, appears ridiculous.

Despite the fact that artificial hair sales soared in the years leading up to the serialized publishing of The Law and the Lady, Major Fitz David belongs to an era when the male wearing of wigs was often treated with comic disdain. ${ }^{49}$ As John Woodforde observes in The Strange Story of False Hair (1971), for men in the nineteenth century, "[w]igs, like false teeth, were considered a shameful vanity." ${ }^{50}$ In Punch, an article appeared in 1855 that mocked a new West End hairdresser who had recently launched a "New Wig Club," which opened its door to only the "titled, the wealthy, and persons of fashion." ${ }_{51}$ Punch exposed this "fashionable" clientele as elderly, vain, and entirely pompous through a slanderous list of imagined rules for the club:

1. The New Wig Club is instituted for the purpose of promoting the privacy of persons who wear wigs or ornamental hair, or who resort to the dyeing process to conceal their greyness.

2. The New Wig Club shall consist of any number of members, who shall be either grey or bald, and any one with black hair who is not bald will be black-balled.

3. Ladies and gentlemen whose hair is beginning to fall off or turn grey may be admitted as honorary members for one month, after which they must either purchase a wig or a bottle of hair-dye, in order to continue to enjoy the privilege of admission. 
4. Each candidate for admission shall be proposed by one member who is bald or grey, and seconded by another; and a lock of the candidate's hair, or if bald, a curl of his wig, shall be hung up for at least one week before the day of the election in the Club-room.

5. No member shall be allowed to vote at an election whose hair has not been dyed, or his wig dressed, within one month from the day of voting.

6. No wash or dye except that supplied by the Club, shall be made up in the Club on any pretence whatever.

7. No member shall bring a stranger into the Club on any pretence whatever.

8. The Club shall be open for the dyeing and hair-dressing of members from ten in the morning until ten at night, except during the London season, when the Club shall be open till midnight.

9. Any defect in a wig or a hair-dye, must be complained of to the Manager of the Club; and if a head is badly dressed, or not done to the turn of a hair, the complaining member may put the curl on the Secretary's box, which must be kept under lock till the complaint is verified. ${ }^{52}$

The emphasis in this piece is very much on the grey and the bald rather than the stylish and/or fashionable, thereby equating wig use with ageing and a condition of supposed desperation. Rule number seven draws our attention to the commercial aspect of wig use, exacerbating the stranglehold that prosthetists had over those unhappy with their incomplete physical appearances.

A much earlier poem, which appeared in the aptly named magazine the Age in 1832, expressed more direct concerns about the way that greedy wig sellers exploited ageing men. "The Old Man and His Grey Wig" tells the story of "An old gentleman, bless'd with a good crop of hair," whose barber "insisted a wig he must wear." 53 The barber disingenuously tells the "old" man that he will lose his hair without the aid of false hair. When the elderly man dismisses the barber's advice, the latter ironically claims that using a wig will save the gentleman hairdressing expenses. This promise proves, unsurprisingly, to be an utter lie. The "old" man eventually agrees to shave his head and purchase a grey wig, but after a year he is shocked when an extortionate bill arrives, including costs for

bleeding, for purge, cauterizing,

For pills anti-bil-ions, and black drafts to swig,

Head-shaving, and trimming, and wig-modernizing,

And lengthy pig-tail to the fusty grey wig..$^{54}$ 
The poem exposes what the anonymous speaker sees as a ruthless exploitation of those susceptible to being conned: in this case, elderly men.

While Collins's depiction of Major Fitz David is arguably less sympathetic to the victim of such a morally bankrupt system, the author does appear to be troubled by a related and, to him, equally immoral financial concern: the concept of marrying for money. In the final chapter of The Law and the Lady, we learn that the Major has successfully married, but we soon realize that his success had little to do with his faux-youthful looks. His new wife, the "plump, round-eyed overdressed girl" aforementioned, reveals to Valeria that she married the Major for financial security:

[I]t was a great deal easier to get the money by marrying the old gentleman. Here I am, provided for-and there's all my family provided for, too- and nothing to do but to spend the money. I am fond of my family; I'm a good daughter and sister $-I \mathrm{am}$ ! See how I'm dressed; look at the furniture: I haven't played my cards badly, have I? It's a great advantage to marry an old man-you can twist him round your little finger. Happy? Oh, yes! ${ }^{15}$

Valeria, no doubt like many Victorian readers of this novel, is disgusted by this young woman's conduct. She states: "When a woman sells herself to a man, that vile bargain is none the less infamous (to my mind), because it happens to be made under the sanction of the Church and the Law." 56 However, the larger point that Collins is getting to here goes beyond highlighting the attitude of this particular character as morally reprehensible. For Collins, society more widely is at fault. This woman's behaviour is undesirable but painfully savvy: she has herself and her family to look after. For her, the easiest and (ironically) most respectful way to achieve financial security is to marry a wealthy, and thus often older, man. Still, the married Major is a shadow of his former self, both physically-looking "hopelessly and undisguisedly" an "old" man—and behaviourally-following his marriage. For example, Valeria describes how the Major "looked at [his wife] submissively between every two words that he addressed to [her]." ${ }^{57}$ The Major's financial status makes him a target for women whose equivalents today are labelled by some as "gold diggers," while his position as an elderly bachelor makes him apparently desperate for the attention of women. This combination, Collins shows, lays the foundations for what the reader imagines will be an unhappy marriage.

Although Collins's scornful tone makes it clear that it is not the Major's physical attractiveness that makes him, in the words of Miserrimus Dexter, 
an "elderly human lap-dog" for women, the Major's wig is a significant aspect of his appearance.$^{58}$ After all, the Major's wig is not just any old wig: it is "a beautiful brown wig," suggesting that it is of a standout quality. Writing two decades earlier, Alexander Rowland wrote that "a peruke, containing only three ounces of hair ... is frequently sold at the price of twenty-five to thirty shillings." 59 Considering that average annual nominal earnings in 1851 were $£ 33.58$, meaning that a wig according to Rowland cost on average over double average weekly earnings, it becomes clear that the Major's wig is a sign of affluence-even if one considers the higher average annual nominal earnings of $£ 53.86$ when The Law and the Lady was published in 1875 , twenty-five to thirty shillings remained a relatively high commodity price. ${ }^{60}$

Despite its high commodity value, in Armadale Bashwood's youthful wig does not signify nearly enough wealth for Collins's ambitious femme fatale anti-heroine Lydia Gwilt. Here, Collins's infamous anti-heroine sets her sights on marrying Allan Armadale, inheritor of the large estate Thorpe Ambrose. When her plan to marry Armadale fails, she concocts another plan to gain possession of the property, this time by way of marriage to Ozias Midwinter, whose real name is also Allan Armadale (he is, in fact, among four Allan Armadales mentioned in the novel). While putting her designs into action, Lydia Gwilt attracts the help of the elder former steward of Thorpe Ambrose, Mr. Bashwood, who is infatuated with her. Bashwood performs duties as a spy for Gwilt. Over the course of his infatuation with Gwilt, Bashwood's wig and false teeth, signifiers of his old age and illegitimacy as a viable match for Gwilt, become indexes of the intensity of his passion. These devices are also comic motifs through which Collins again critiques the social pressures that drive individuals to present themselves in this way.

When we first meet Bashwood, he is described in the following manner:

He was a lean, elderly, miserably respectable man. He wore a poor old black dress-coat, and a cheap brown wig, which made no pretence of being his own natural hair. Short black trousers clung like attached old servants round his wizen legs; and rusty black gaiters hid all they could of his knobbed, ungainly feet. Black crape added its mite to the decayed and dingy wretchedness of his old beaver hat; black mohair in the obsolete form of a stock drearily encircled his neck and rose as high as his haggard jaws. The one morsel of colour he carried about him was a lawyer's bag of blue serge, as lean and limp as himself. The one attractive feature in his clean-shaven, 
weary old face was a neat set of teeth-teeth (as honest as his wig) which said plainly to all inquiring eyes, "We pass our nights on his looking-glass, and our days in his mouth." 61

As with Miss Notman's wig, we see Bashwood's false hair and teeth reflect his personality: "honest," "cheap," and unconvincing. We sense that even though he uses devices that would be considered vestiges of vanity, he has more likely than not been tricked or otherwise coerced into using these primarily cosmetic prostheses: his appearance is otherwise a little on the shabby side of neat and rather reserved, suggesting that he is not vain per se.

Amid his humble attire, Bashwood's anomalous prostheses provide a subtle reference, on the one hand, to the social pressure to look young and physically complete, and, on the other hand, to the persuasiveness of contemporary commercial prosthesis rhetoric. The conspicuousness of Bashwood's prostheses, considered alongside his weak persona, imply that he may have fallen victim to the misleading marketing of prostheses. But when we read Collins's next description of Bashwood, it becomes even clearer that his prostheses are analogous to his feebleness as a character:

There, perched comfortless on the edge of his chair, sat the poor brokendown, nervous wretch, in his worn black garments, with his watery eyes, his honest old outspoken wig, his miserable mohair stock, and his false teeth that were incapable of deceiving anybody - there he sat, politely ill at ease; now shrinking in the glare of the lamp, now wincing under the shock of Allan's sturdy voice; a man with the wrinkles of sixty years in his face, and the manners of a child in the presence of strangers; an object of pity surely, if ever there was a pitiable object yet! ${ }^{62}$

Here, Collins emphasizes Bashwood's unfortunateness through a series of oxymoronic descriptions. The elderly steward has an "outspoken wig" and "false teeth that were incapable of deceiving anyone." Though he is "a man with the wrinkles of sixty years," he has the "manners of a child in the presence of strangers." ${ }^{63}$ His appearance thus fails him on several accounts: his prostheses are blatant and his haggard face-often a symbol of experience, self-assuredness, and sagacity - contrasts his timid, withdrawn, and childlike behaviour. Bashwood's prostheses do not enable him to pass as youthful and whole; instead, they expose him as an elderly man trying to look vigorous. 
The appearance of Bashwood's prostheses, however, changes significantly after he has run errands for his beloved Miss Gwilt. By this point, Bashwood's affections have matured to a stage whereby he idolizes the ground that Gwilt walks on. For instance, when catching sight of her prior to a rendezvous, Bashwood mutters to himself: "I wish I was the ground she treads on! I wish I was the glove she's got on her hand!" His prostheses, as well as his appearance in general, are presented in more refined but nonetheless ridiculous terms: "His personal appearance had been apparently made the object of some special attention. His false teeth were brilliantly white; his wig was carefully brushed; his mourning garments, renewed throughout, gleamed with the hideous and slimy gloss of cheap black cloth. He moved with a nervous jauntiness, and looked about him with a vacant smile." ${ }^{64}$ Here, in an ironic shift, Bashwood's finely groomed prostheses accentuate the artificiality and grotesqueness of his appearance. His dentures appear "brilliant white," a colour of teeth that few would have achieved in this period. ${ }^{65}$ While many strove for white teeth, as we can see from the burgeoning trade of the teeth-whitening-powder in this period, few managed to maintain "pearly whites"-due, in part, to the often damaging role played by falsely heralded whitening powders, which tended to be so gritty that they wore away tooth enamel as well as stains. ${ }^{66}$ Those who did achieve teeth whiteness from a rigorous hygiene routine, or the use of artifice, were not always depicted in the most positive lights. Mr. Carker from Dickens's Dombey and Son, for example, is described at regular intervals as bestial because of the immaculate whiteness of his teeth. Dickens's depiction can be considered in relation to contemporaneous depictions of white-toothed vampire figures, such as Sir Frances Varney from James Malcom Rymer's popular penny dreadful Varney the Vampire ([1845-1847]). ${ }^{67}$ Bashwood's white teeth thus not only appear out of place in context with his ageing face but also signify an almost parasitic element to his character, associating him with earlier vampire and vampire-like figures, including Varney and also Heathcliff in Emily Brontë's Wuthering Heights (1847). ${ }^{68}$ The notion of a creepy, elderly, white-toothed man who preys on younger women is thus conjured, but ultimately it is Bashwood who is the victim of Gwilt's almost mesmeric influence over him.

Above all, Bashwood's prostheses provide the reader with an index for the elderly steward's desperate passion for Gwilt. As his prostheses become more polished, and ironically more visible, his feelings towards Gwilt also intensify. When Bashwood eventually realizes that he is being played, he 
"lift[s] his youthful wig a little from his bald old head," emphasizing its symbolic closeness to his passions. ${ }^{69}$ To use Bill Brown's framework, here "we begin to confront the thingness" of Bashwood's wig: the object "stops working" for Bashwood, thereby further emphasizing its "thingness" to the reader. ${ }^{70}$ The "thingness" of the device was brought to our attention much earlier, since it never functioned effectively, but at this point the narrative places a strong focus on it. The wig's pretence as a natural part of Bashwood is obliterated through action. The lifting of the wig is an act of resignation. Bashwood's attempts to look younger are no longer needed as his chances with Gwilt, though non-existent to begin with, become clear to him at last. The torment that he experiences is simultaneously both cruelly humorous and pitiful, underlining Collins's complex satire of the social pressures that might encourage ageing men to act like Bashwood.

\section{LOSING ONE'S Wig}

Collins was hardly the only Victorian writer to make fun of ageing prosthesis users. The late nineteenth-century periodical press used the prosthesis mishap as a major trope. This trope, though popular from early in the century, really took off from the 1870s onwards, reflecting developments in journalistic style and prosthesis manufacture. The "New Journalism" that emerged in the 1870s and 1880s, which brought an investigative and sensational tone to the exposure of scandals and intrigues, responded to the increasingly competitive marketplace by becoming more attuned to consumers' preferences for stories about popular culture. As Mark Hampton notes, savvy editors recognized that readers "cared less about Home Rule or Bulgarian atrocities" than about "football scores, divorce cases, murder trials, and fashionable dresses." "As "As a result," Nicholson writes, "parliamentary reports, financial bulletins and local news items gave way to serialized fiction, household tips, children's pages, gardening advice, poetry, competitions and comic clippings." 72 Alongside these developments, prostheses, such as dentures and wigs, became increasingly prevalent in society. By 1878, for instance, one could purchase a complete set of teeth in vulcanite form from $£ 44 \mathrm{~s}$-half the price of a set that had gold uppers. ${ }^{73}$

In the stories that appeared in periodicals from this period, we often see ageing or elderly prosthesis users, whose wigs blow off in the wind, whose false teeth fall out or otherwise malfunction, or whose cover is blown by 
an innocent observer-often a child or animal. These depictions, like Collins's, at surface level display an unsympathetic attitude to those in physical decline, reinforcing conceptual tensions and divides between the organic and the artificial, and youth and old age. Even though they are presented in a predominantly ableist and often ageist fashion, such stories implicitly challenge the predominant regime of privileging physical wholeness and youth, since they draw our attention to the incongruity of the false body part on the aged subject. Central to these representations from the periodical press is the incompatibility of the human with the technological appendage. My contention is that these representations, while clearly humorous, were not simply frivolous depictions used to stimulate easy laughs. Instead, these engagements use comedy as a vehicle through which to call into question both the proliferation of certain prosthetic technologies and the very logic behind these devices.

The image of a prosthesis falling off an elderly figure or malfunctioning became increasingly popular in the nineteenth century. We see this image replicated numerous times in sources such as Grace Goldney's 1870 serialized novella Marion's Choice, in which an elderly man's hat and wig are blown down the street by a strong gust of wind; William Henry Archibald Chasemore's 1878 Judy cartoon "Wicklebury's Wig," which depicts a similar situation facing an elderly bachelor who purposely bought a new wig to impress a particular woman; the 1891 Funny Folks short story "Mr. Sagtooth's First Appearance," which represents an elderly, wig-wearing man, whose wig falls off during an impromptu theatrical performance, causing a comic stir; and Harold Copping's circa 1895 illustration for F. Scarlett Potter's 1895 novel Hazelbrake Hollow, "It caught his wig and jerked it into the air," which portrays another elderly man, whose wig is taken off by the hook of a fishing line. ${ }^{74}$ Though decidedly less accidental, the Fun cartoon "Retributive Justice" (1879) shows the results of an elderly female false teeth user being hit in the mouth with a snowball: it “disarranged her artificial teeth, so that she couldn't close her mouth, and, thinking she had lockjaw, she sat down in the snow and screamed horribly" (see Fig. 6.5). In each of these cases, the prosthesis is primarily a motif of light amusement. Laughter is stimulated by the irony of the scenarios depicted: a device used solely to disguise physical loss and thereby hide one's "shame" is suddenly removed or displaced, unwittingly exacerbating the embarrassment of the user, who is not only unveiled as incomplete but also exposed as vain and/or fraudulent. The shock, panic, and/ or embarrassment of the prosthesis user losing or having damaged his or 


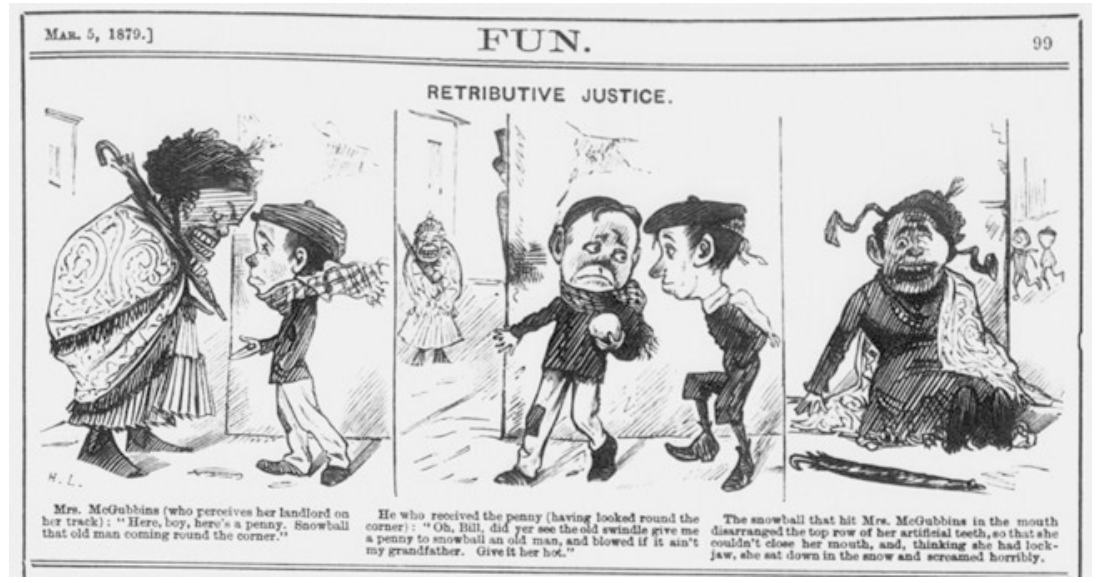

Fig. 6.5 A cartoon showing how dentures can malfunction-in this case, because of a direct hit from a snowball. "Retributive Justice," Fun 29 (1879): 93. Image published with permission of ProQuest. Further reproduction is prohibited without permission

her artificial body part adds to the hilarity of the scenario. For instance, the facial expression and body language of Wicklebury in Chasemore's cartoon is typically stunned and thus conducive of laughter.

In relation to the human-technology interface, the wig was often depicted as a device that almost never manages to successfully convince those around it that it is natural. As C. D. Shanly wrote in an article for The Treasure of Literature and the Ladies' Treasury in 1872: "Few things adopted with intention to deceive are less deceptive than wigs." ${ }^{75}$ Its shortcomings in this respect are exacerbated when it falls off. Instances of prosthesis failure suggest that there is too great a discrepancy between the real and the artificial for the latter to successfully mimic and integrate fully with the former. The losing of one's wig shows, on the one hand, a practical dilemma about fixing a wig to an often-bald head, and, on the other hand, a conceptual contrast between the natural and the manmade. Woodforde shows us that those men ordering wigs to disguise baldness were asked to provide very precise measurements to manufacturers in order to ensure a good fit, a natural-looking appearance, the lessening of any peruke slippage. ${ }^{76}$ There was also a variety of fixatives available to secure wigs to heads, including springs, strings, pastes, gums, and even the 
"Golden Cement":" a product advertisements stated would "stick [a wig] tight on the head, and not move, as if it had grown there." 77 Still, cultural depictions suggest that wigs fell off at an embarrassing rate.

In addition, we also see artificial hair's unconvincingness in scenes where it is noticed and/or removed by seemingly innocent parties, including animals and children. A humorous example appears in G. Renaud's 1887 cartoon "Waggles's Wig." ${ }^{78}$ In this story, a vain and ageing dandy visits a woman named Lady Trabazon, clearly with the intention of wooing her and/or her more youthful female companion. Upon his arrival, Lady Trabazon's pet marmoset takes a clear interest in the well-presented man. During Waggles's conversation with Trabazon, the marmoset mischievously steals his wig. Chaos ensues. In "The Story of Gaffer Grey" (1871), an elderly man's wig goes missing after a jackdaw takes it to make a nest with. Meanwhile, in C. E. Pearce's "Princess Prettypet" (1873), a mischievous Princess plays a trick on her music Professor by tying his wig to a sleeping dog, which when awoken by cries of "cats," wakes up and tears the false hair to shreds. The same is the case in "The General's Wig" (1875), where an elderly General's wig is stolen and destroyed by a cockatoo. ${ }^{79}$ Along similar lines, in the 1880 Boys of England serial The GoodNatured Boy; or, What Came of It, a mischievous parrot directs an innocent boy into a matron's room while she is getting changed. ${ }^{80}$ As the boy discovers, much to the matron's chagrin, she wears false teeth and a glass eye. She whips him with a wet towel as a punishment.

What these representations suggest is that even supposedly unenlightened animals were able to perceive the anomalousness of a prosthesis on an elderly person. Moreover, these cultural works recall an observation of Mark Twain, who held critical views about humanity when compared to so-called Higher Animals. In his 1896 essay “Man's Place in the Animal World," Twain compared humankind's frailty and reliance on technology to the adaptive prowess of "Higher Animals":

For style, look at the Bengal tiger-that ideal of grace, beauty, physical perfection, majesty. And then look at Man-that poor thing. He is the Animal of the Wig, the Trepanned Skull, the Ear Trumpet, the Glass Eye, the Pasteboard Nose, the Porcelain Teeth, the Silver Windpipe, the Wooden Leg - a creature that is mended and patched all over, from top to bottom. If he can't get renewals of his bric-a-brac in the next world, what will he look like? ${ }^{81}$ 
Twain's words critique the ways in which humans deal with the physical decline that accompanies old age. The examples that he provides, including ear trumpets, false teeth, and artificial legs, in addition to his choice of verbs to describe the process of fighting senescence- "mended" and "patched"- draw our attention to the view that the human body cannot successfully integrate with technology; at best, its blemishes can be patched up with non-human parts, but even then its reconstitution is but a temporary-and unconvincing-fix. Twain elsewhere mocks the fashion for prostheticizing the body in physical decline. In his semi-autobiographical 1872 travel book, Roughing It, Twain describes a group of elderly women who happily lend each other prostheses for social occasions: "[Miss Jefferson] had a glass eye and used to lend it to old Miss Wagner, that hadn't any, to receive company in; it warn't big enough, and when Miss Wagner warn't noticing, it would get twisted around in the socket, and look up, maybe, or out to one side, and every which way, while t' other one was looking as straight ahead as a spy-glass." 82 For Twain the grotesque use, or rather misuse, of artifice exemplified the shabbiness of the human condition.

Twain's depiction of prosthesis misuse brings us to the several tales that focus on the inability of the elderly to use prostheses correctly. In typical, comic fashion, in Alfred Edersheim's 1873 novel Shorn to the Wind, a pastor's wife, who has one arm, ironically carries her prosthesis in a shopping basket instead of using it for practical purpose. ${ }^{83}$ Similarly, a popular anecdote, one reprinted several times, tells the story of an elderly woman who had been taken to court by an ocularist after she refused to pay for a glass eye. ${ }^{84}$ The woman explains that her artificial eye "is not half the use of my wig and artificial teeth, for I cannot see out of it a bit." 85 In another humorous sketch, an elderly woman asks a friend that wears a glass eye why she did not ask for her eye to be made from more transparent glass so that she could see out of it. ${ }^{86}$ These short fictions once again open a conceptual divide between the natural and the artificial and, in fact, complicate the cultural association of the ageing with the prosthetic. These examples suggested that elderly people were out of touch with modern innovation and thus unable to use prosthetic devices to their full potential. 


\section{DazZling Devices and Unlikely Heroes}

The non-normative use of a prosthetic device by a subject experiencing physical decline is a motif taken up with surprising frequency in latecentury imperial adventure stories. As I will show in this final section, these depictions drew from the contemporary cultural mocking of vain elderly prosthesis users, while further complicating the social pressures that encouraged this behaviour by presenting past-their-best prosthesisusing male imperialists as unlikely heroes. The combination of a device that is perceived to be remarkable with an unlikely ageing hero provides a fascinating comic contrast. In several imperial adventure stories, the artificial body parts of ageing imperialists are perceived by non-Western subjects as objects of awe in comical and narratively significant scenes. ${ }^{87}$ In Haggard's King Solomon's Mines (1885), Captain John Good's false teeth save the lives of him and his comrades after the dentures are seen by some hostile Kukuanaland warriors as signifiers of divinity. Similarly, and perhaps derivatively, McKean's “A Wig and a Wooden Leg” (1886) tells the story of a wig-wearer and a wooden-leg user, who while working for the same imperial trader are saved in separate attacks from aggressive "Indians" thanks to their respective prostheses being perceived as magical. In the Pick-Me-Up magazine narrative poem "A Cure for Cannibalism" (1889), an artificial eye saves one Mr. Brown from being eaten by cannibals in Central Africa:

The savages were thunderstruck, and marvelled at the fellow. Who made them turn a colour that approached a greeny-yellow.

With many gestures indicating the consensus of the meeting, That such a clever party was by far too good for eating. ${ }^{88}$

These prostheses have been understood as examples of ethnocentrismrevelatory of a Western arrogance that mocks non-Westerners for having supposedly absurd beliefs regarding, or unenlightened approaches to, technology. ${ }^{89}$ Yet, key comic aspects of these stories have been neglected. The humour stems from a couple of factors relating to the intersections of ageing and prosthesis use: namely, from the way that prostheses become symbols of ageing, thus making their users appear unlikely heroes, and from the unlikelihood of the prosthesis itself as a device that incites fear.

Kay Heath's scholarship on midlife provides a critical framework to examine the transitional life stage between youth and old age that the 
imperial prosthesis users embody. Midlife, though first defined in an English language dictionary in 1895 , was very much a part of the social consciousness for much of the nineteenth century": "Whereas old age is depicted as a final stage increasingly associated with the end of certain activities and identities-lessened marriageability, waning sexuality, and retirement from work - midlife ... stress[es] the possibility that [a] character's fortunes may go either way, from acquiescent decline to a sustained youthfulness." ${ }^{91}$ Each of the imperialists described tread this liminal stage of ageing as they perform adventurous deeds, displaying youthful vitality, while their bodies show visible signs of decline. Most significantly, it is the "past-one's-best" persona of each character that is key to both the laughter produced by his interactions with prosthesis and the challenging of physical preferences that each story contributes to.

The impression that the four imperialists are "past-one's-best" emerges when we learn that all of them are seasoned individuals. Good was in the navy for seventeen years before being "turned out"—a sign in itself that he is past his prime when the reader meets him. ${ }^{92}$ In McKean's story, it is apparent that the wig-wearer is an imperialist of considerable experience as it is reported that he was scalped by Native Americans "several years before" his second encounter with the violent indigenous people. ${ }^{93}$ In "A Cure for Cannibalism," we learn that Mr. Brown is a veteran explorer, implying that he is not youthful. Furthermore, after escaping death, the cannibals call him "father."

Each character also displays the physical cost of years of work overseas. Haggard's narrator, Quatermain, describes Good as an extremely neat but "curious man to look at." 95 Good is physically unimpressive in comparison to his companion Sir Henry Curtis, "the biggest-chested and longestarmed man [that Quatermain] ever saw." 96 Good is of a medium height and stout. He is later described as having a "sickly" face by a bewildered Kukuanaland warrior. ${ }^{97}$ More pressingly, Good is extremely reliant on technological adornments - not just a pair of false teeth but also an eye glass. Quatermain alludes to Good's heavy reliance on his eye glass when he jokes: "I thought he used to sleep in it, but afterwards I found that this was a mistake." 98 Prostheses are thus indicators of Good's deteriorating physical capacities and thereby his premature ageing.

Equally, these devices are symbols of his midlife status since they are representative of his attempts to stave off the functional and aesthetic signs of ageing, highlighting his liminal status between youth and old age. In this same way, we can see Mr. Brown's use of an artificial eye and the 
traders' use of prostheses in McKean's sketch as indicators of physical decline-though eye and limb loss are not signifiers of ageing per se, here they imply that the adventurers are "worn out" or "used up" (to use Poe's phrase) by their excursions. ${ }^{99}$ In a time when a healthy body was believed a measure of youth, vigour, and self-assertion, perceived prosthesis use became a cultural shorthand for waning vitality, since nineteenth-century concepts of health relied upon an ideal of physical integrity. ${ }^{100}$ Thus, the characters described are not old, but they display evident signs of decline. Because their prostheses become visible, the devices become insignias of ageing. To some extent, the characters also show that sometimes it is not the number of years lived but rather how difficult those years have been that determines one's age in cultural terms. These imperial adventurers show signs of wear and tear, undoubtedly because of their physically taxing and mentally stressful lives, which, one could argue, make them appear old beyond their years.

It is therefore the irony of each figure's bizarre success that makes their stories such sources of intrigue and comic amusement. Heath has shown us that as the nineteenth century progressed, male midlife became an increasingly stressful time as growing emphasis was placed on physicality as a fundamental aspect of masculinity. ${ }^{101}$ The emergence and popularity of muscular Christianity with its emphasis on physical brawn, which as Norman Vance argues came about amidst a climate of "emerging individual possibility" between the 1832 and 1867 reform bill, is an important context that Heath shows cultivated anxiety about declining physical prowess among men entering midlife. ${ }^{102}$ Furthermore, the fact that "manliness became defined by profession and capacity to work" meant that "waning strength and a sense of unfitness for new times feminized older men, excluding them from power." ${ }^{103}$ Regarding the empire, John Tosh notes that strength and endurance were seen as essential traits for maintaining colonial rule-a point that clearly relates to each midlife male prosthesis user described in this section. ${ }^{104}$ Because each imperialist is a prosthesis user and thus physically incomplete, he appears diminished when considered alongside late Victorian idols of male physicality such as Eugen Sandow or Sir Henry Curtis from Haggard's novel. Sandow and Sir Henry are both imposing and conspicuously physically complete. What is thus amusing, and somewhat transgressive, in the stories under discussion is that unassuming midlife men are depicted as action heroes-in some cases ironically thanks to the very prostheses that signify their physical decline. 
Good, once again, provides the best example to illustrate this point. Despite being a poor shot and somewhat of a bumbling fool in general in terms of his interactions with technological devices, in several instances, to the surprise of both his Western comrades and the reader, his actions save the day. For instance, most memorably, his bizarre, half-dressed attire - with half of his face shaven and his white legs exposed-and idiosyncratic use of false teeth ("dragging the top set down and allowing them to fly back to his jaw with a snap") frighten the Kukuanaland people into thinking that he and his friends are spirits who should be worshipped and respected rather than attacked. ${ }^{105} \mathrm{He}$ also later provides medical attention to himself and his friends after their violent escapades in the Kukuanaland civil war.

These heroic deeds provide an ironic contrast to the numerous points where he is shown to be the weak link out of Haggard's three white adventurers. In Chapter 4, Good "[falls] a victim to his passion for civilised dress," almost getting trampled to death by a wounded elephant after being "cumbered" by his inappropriate choice of trousers. He then falls over after his polished boots give way under him. In the next chapter, while leading his companions through the desert, Good literally stumbles upon a herd of sleeping quagga (a subspecies of zebra), where he is whisked off into the distance on the back of one. In Chapter 14, he is injured in the battle against Twala's army, which causes him to fall into a life-threatening high fever. In Chapter 18, after Gagool entraps the white men in Solomon's treasure chamber, he is the first to give up hope, reasoning, "What is the good in eating? ... the sooner we die and get it over the better." We can associate nearly all of Good's shortcomings with stereotypes of ageing. He attempts to look younger (exemplified by his "passions for civilised dress"); he exhibits signs of mental decline (shown by his mishap with the quagga); and he demonstrates inherent pessimism (displayed by his giving up on hope in the treasure chamber scene). ${ }^{106}$ It is thus surprising, amusing, and somewhat transgressive in terms of the cultural preoccupation with youth, physical integrity, and strength that a character with these apparent flaws manages to perform the important heroic deeds listed previously.

The fact that it is a pair of false teeth that elicits awe from the Kukuanaland warriors is plainly ironic and therefore comical. ${ }^{107}$ In the case of King Solomon's Mines, underpinned by an ethnocentric logic, the narrative encourages readers to laugh at the Kukuanaland people 
because they are unable to perceive the artifice of Good's teeth; they think that the teeth are real and that Good can remove them at will because he possesses magical powers. A final comic aspect of Good, which is linked to his use of false teeth, is his extreme vanity-a trait commonly mocked in relation to ageing in Victorian literature and culture. Many of the comic moments in the story, including the scene in which Good's bizarre, half-dressed appearance convinces the Kukuanaland people that he and his friends are spirits, can be linked to this aspect of his character. His near misses with death, such as when he "[falls] a victim to his passion for civilised dress" can also be linked to his vanity. Good is thus depicted as absurd, as someone who uses cosmetic aids in inappropriate environments-according to Quatermain, he is "the neatest man [he] ever had to do with in the wilderness." ${ }^{08}$ But for many Victorians, Good's inclination towards cosmetics would have seemed ridiculous not just because of his decision to use them "in the wilderness"; the ageing and vain were also represented and discussed as a hilariously hopeless group deserving of mockery.

Haggard's portrayal of Good, however, is not simply a cruel slight against those deemed past their best. The character's prosthesis use fits within a wider cultural critique of vanity, and this criticism serves as a subtle, playful, and humorous curveball against the hegemony of youth and ability. Good's characterization therefore complicates the idolatry displayed towards the chiselled and complete bodies of Sir Henry and Umboppa in Haggard's novel. It is well documented that Haggard's adventure story, like its inspiration Robert Louis Stevenson's Treasure Island (1881-1882), was written for "boys of all ages." 109 Good's representation as an unlikely hero whose signs of physical decline are all too apparent provided humour but also fantasy appeal and perhaps even hope to his Victorian midlife male readers.

The sources that I have examined in this chapter consolidated a trope that continues to saturate cultural images of the elderly today. Associations of certain forms of prostheses such as dentures with old age remain so prominent and negative that modern advertisements for products, including denture adhesives, almost never feature direct images of false teeth or elderly users. ${ }^{110}$ The conspicuous absence of the prosthetic device shows how influential the legacy of humorous and grotesque depictions of these devices and their elderly users has been. 
Nineteenth-century depictions satirized not only the ageing users of such devices but a society that invested too heavily in appearances of youth and physical wholeness. There is thus much that we can learn from these portrayals. We need to look at, and perhaps even laugh at, our own social prejudices to ensure that the lives of the elderly who choose to use prostheses remain free from stigma.

\section{Notes}

1. This poem appeared in New England Quarterly, Spirit of the Public Journal, and Sporting Magazine in 1802. It then appeared in full, abridged, or adulterated form in the following: Monthly Review in 1803, Gentleman's Magazine in 1804, Lady's Monthly Magazine in 1807, Satirist in 1837, and Penny Satirist in 1838.

2. Pat Thane, "Epilogue," in Interdisciplinary Perspectives on Aging in Nineteenth-Century Culture, eds. Anne-Julia Zwierlein, Katharina Boehm, and Anna Farkas (New York: Routledge, 2014), 232-33.

3. Edgar Allan Poe, "The Man That Was Used Up: A Tale of the Late Bugaboo and Kickapoo Campaign," in The Works of the Late Edgar Allan Poe, by Edgar Allan Poe, vol. 4 (New York: Blakeman \& Mason, 1859); Charles Dickens, Dombey and Son (London: Penguin, 2002); Wilkie Collins, Armadale (Oxford: Oxford University Press, 1999).

4. George R. Boyer and Timothy P. Schmidle, "Poverty among the Elderly in Late Victorian England," The Economic History Review 62, no. 2 (2009): 250.

5. Anne-Julia Zwierlein, Katharina Boehm, and Anna Farkas, eds., Interdisciplinary Perspectives on Aging in Nineteenth-Century Culture (New York: Routledge, 2014), 1.

6. Karen Chase, The Victorians and Old Age (Oxford: Oxford University Press, 2009).

7. Pat Thane, Old Age in English History: Past Experiences, Present Issues (Oxford: Oxford University Press, 2002).

8. Chase, The Victorians, 6.

9. Mr. Scott, Surgeon and Mechanical Dentist, Advertisement, Bell's Life in London and Sporting Chronicle 417 (1830): 2.

10. Multiple classified advertisements, Lady's Newspaper, no. 599 (1858): 399.

11. Messrs. Mosley's Teeth and Painless Dentistry, Advertisement, Bell's Life in London and Sporting Chronicle 2, no. 365 (1867): 3.

12. For representations of aged wooden-leg-using Greenwich and Chelsea pensioners, see, for example, Gruff and Glum in Charles Dickens, Our Mutual Friend (London: Everyman, 2000); "Laid up at Greenwich," 
Judy: or The London Serio-Comic Journal, December 2, 1868; "The Rewards of Warfare," Kind Words: A Week-Day Magazine for Boys e Girls, November 24, 1870; "A Strange Complaint," Fun, February 18, 1871. For elderly peg-leg-using beggars, see "Thrift, or Nothing Is Useless," Chambers's Edinburgh Journal 1, no. 38 (1844); [Richard H. Horne], "Dust; or Ugliness Redeemed," Household Words 1, no. 16 (1850); and the article "Mr. Wegg and His Class," All the Year Round 18 , no. 441 (1877).

13. Regarding military surgery, Henry Robert Heather Bigg wrote, "many a soldier comes home with what is surgically a splendid stump, but a most inappropriate one mechanically, and to my knowledge it has frequently been found advisable by medical officers attached to the military hospitals at home to re-operate ... in order to get better ones." Henry Robert Heather Bigg, Artificial Limbs, and the Amputations Which Afford the Most Appropriate Stumps in Civil and Military Surgery (London: Henry Robert Heather Bigg, 1885), 103. In terms of monetary provisions, half a century earlier Henry S. Richardson observed that Privates housed at Greenwich Hospital received $1 \mathrm{~s}$ pocket money per week in addition to "lodging, clothing, and maintenance." Henry S. Richardson, Greenwich: Its History, Antiquities, Improvements, and Public Buildings (Greenwich: Harriet Richardson, 1834), 42. For context, $1 \mathrm{~s}$ was thirty times less than a weekly wage that would have provided "a very comfortable workingclass income" Simon Eliot, "The Business of Victorian Publishing," in The Cambridge Companion to the Victorian Novel, edited by Deirdre David (Cambridge: Cambridge University Press, 2000), 37.

14. John Morreall, "Humour and the Conduct of Politics," in Beyond a Joke: The Limits of Humour, ed. Michael Pickering and Sharon Lockyer (Basingstoke: Palgrave, 2005), 66. The incongruity model differs from the superiority model, which dominated from the time of Plato to the eighteenth century. The superiority model suggested that humour emanates from a feeling of superiority over either someone else or a former state of ourselves. A third model for understanding how humour functions is the relief model, which suggests that laughter is the release of energy in the nervous system that has been suddenly rendered unneeded (Morreall, "Humour," 65-68). Morreall shows how the release model overlaps with the incongruity model ("Humour," 67-68).

15. Stephen Leacock, Humor: Its Theory and Technique, with Examples and Samples; a Book of Discovery (New York: Dodd, Mead, 1935), 15.

16. Mitchell and Snyder, Narrative Prosthesis; Tom Coogan and Rebecca Mallett, "Introduction: Disability, Humour and Comedy," Journal of Literary \& Cultural Disability Studies 7, no. 3 (2013).

17. Coogan and Mallett, "Introduction," 68. 
18. Morreall, "Humour," 67-68.

19. Tom Shakespeare, “Joking a Part," Body \& Society 5, no. 4 (1999): 49.

20. For more on the rise of this genre, see Diana Donald, The Age of Caricature: Satirical Prints in the Reign of George III (New Haven: Yale University Press, 1996).

21. Jonathan Swift, "A Beautiful Young Nymph Going to Be," Poetry Foundation, accessed July 2, 2018, https://www.poetryfoundation.org/ poems $/ 50580 /$ a-beautiful-young-nymph-going-to-bed.

22. Simon Dickie, "Hilarity and Pitilessness in the Mid-Eighteenth Century: English Jestbook Humor," Eighteenth-Century Studies 37, no. 1 (2003). Elsewhere, as Amelia F. Rauser has shown us, caricatures focusing on the excessiveness of wigs were regularly used to criticize macaronis. Amelia F. Rauser, "Hair, Authenticity, and the Self-Made Macaroni," EighteenthCentury Studies 38, no. 1 (2004).

23. Chase, The Victorians, 276.

24. John Woodforde, The Strange Story of False Teeth (London: Routledge and Kegan Paul, 1968), 87-92.

25. Galia Ofek, Representations of Hair in Victorian Literature and Culture (Aldershot: Ashgate, 2009), 28.

26. Woodforde, The Strange, 2.

27. Edgar Allan Poe, "The Spectacles," in Prose Tales (Second Series) Arthur Gordon Pym, by Edgard Allan Poe (Boston: Dana Estes, 1884).

28. Poe, "The Man," 315.

29. Poe, "The Spectacles," 164, 195, 194, and 172.

30. E. T. A. Hoffman, "The Sandman," in Tales from the German, Comprising Specimens from the Most Celebrated Authors, trans. John Oxenford and C. A. Feiling (London: Chapman and Hall 1844), Project Gutenberg, last modified April 18, 2010, https://www.gutenberg.org/ files/32046/32046-h/32046-h.htm.

31. Sharrona Pearl, About Faces: Physiognomy in Nineteenth-Century Britain (Cambridge: Harvard University Press, 2010), 221.

32. Martha Stoddard Holmes and Mark Mossman, "Disability in Victorian Sensation Fiction," in A Companion to Sensation Fiction, ed. Pamela K. Gilbert (Chichester: Wiley-Blackwell, 2011), 493.

33. Wilkie Collins, The Black Robe (London: Chatto and Windus, 1910).

34. Lisa Niles, “Owning 'the Dreadful Truth'; or, Is Thirty-Five Too Old?: Age and the Marriageable Body in Wilkie Collins's Armadale," Nineteenth-Century Literature 65, no. 1 (2010): 68.

35. Niles, “Owning," 77-79.

36. Qtd. in ibid., 78.

37. Niles, “Owning," 79. 
38. Collins, The Black, 67-68.

39. William Makepeace Thackeray, The Virginians, 2 vols. (London: Bradbury and Evans, 1858-1859); Anthony Trollope, The Way We Live Now (London: Penguin, 1994).

40. Collins, The Black, 67.

41. Margaret Morganroth Gullette, Aged by Culture (Chicago: University of Chicago Press, 2004), 161-62.

42. Collins, The Black, 67-68.

43. Susan Sontag, "The Double Standard of Aging," in Psychology of Women: Behavior in a Biosocial Context, ed. Juanita H. Williams, 3rd ed. (London: Norton, 1987).

44. Collins, The Law, 59-60.

45. Ibid., 62 .

46. Ibid., 190.

47. Ibid., 64 .

48. Ibid., 59.

49. Ofek, Representations, 37; Collins, The Law, 189, 263, and 408.

50. John Woodforde, The Strange Story of False Hair (London: Routledge and Kegan Paul, 1971), 76.

51. "The New Wig Club," Punch, May 26, 1855, 209.

52. Ibid.

53. "The Old Man and His Grey Wig." The Age, February 12, 1832.

54. Ibid.

55. Collins, The Law, 409.

56. Ibid., 409-10.

57. Ibid., 408.

58. Ibid., 257.

59. Alexander Rowland, The Human Hair, Popularly and Physiologically Considered with Special Reference to Its Preservation, Improvement and Adornment, and the Various Modes of Its Decoration in All Countries (London: Piper, Brothers \& Co., 1853), 159. Thomas Elliott, "Hair Cutter, Hair Grower, Wig Maker, and Perfumer," of Fenchurch Street, London, advertised his "Feather-weight wigs" for $£ 110$ s circa 1860, verifying Rowland's estimate. Thomas Elliott, Hair Cutter, Hair Grower, Wig Maker, and Perfumer, advertisement, [c.1860], EPH 160B, hair care box 9 , Wellcome Library, London.

60. Gregory Clark, "What Were the British Earnings and Prices Then? (New Series)," Measuring Worth, accessed July 2, 2018, http://www.measuringworth.com/ukearncpi/.

61. Collins, Armadale, 236-37.

62. Collins, Armadale, 279. 
63. Ibid.

64. Ibid., 454.

65. As Woodforde notes, "[toothbrushes] were rarities, or at any rate luxuries, till after about 1850." Chandra and Chandra suggest that the term "oral hygiene" was not even coined until 1884. Woodforde, The Strange Story of False Teeth, 45; Satish Chandra and Shaleen Chandra, Textbook of Community Dentistry (New Delhi: Jaypee Brothers Publishers, 2002), 7.

66. Woodforde, The Strange Story of False Teeth, 43.

67. Varney is described at one point as having an "almost beautiful smile, which displayed his white glistening teeth to perfection." [James Malcom Rymer], Varney the Vampire; or, The Feast of Blood, Project Gutenberg, last modified October 4, 2011, http://www.gutenberg.org/ files/14833/14833-h/14833-h.htm, ch. 8.

68. In Chapter 34 of Brontë's novel, Heathcliff is described as having "sharp white teeth." Emily Brontë, Wuthering Heights (London: John Murray, 1910), Project Gutenberg, last modified August 28, 2010, https://www. gutenberg.org/files $/ 768 / 768$-h/768-h.htm. For more on the way that Brontë evokes debate concerning Heathcliff's possible status as a vampire, see Carol A. Senf, The Vampire in Nineteenth Century English Literature (Madison: University of Wisconsin Press, 2013), 75-93.

69. Collins, Armadale, 566.

70. Bill Brown, “Thing Theory," Critical Inquiry 28, no. 1 (2001): 4.

71. Mark Hampton, Visions of the Press in Britain, 1850-1950 (Urbana: University of Illinois Press, 2004), 119.

72. Nicholson, “Jonathan's Jokes," 37.

73. See Mr. H. Lyon and Mr. Tindall, Dentists, advertisement, Ipswich Journal, January 2, 1878. Before the introduction of vulcanite, gold and ivory were the most popular materials used for making denture bases (Woodforde, The Strange Story of False Teeth, 87-88).

74. Grace Goldney, Marion's Choice, Aunt Judy's Magazine 8, no. 112-14 (1870); William Henry Archibald Chasemore, "Wicklebury's Wig," Judy, January 2, 1878; “Mr. Sagtooth's First Appearance," Funny Folks 17, no. 853 (1891); Harold Copping, "It Caught His Wig and Jerked It into the Air," wood-engraved illustration, in Hazelbrake Hollow, by F. Scarlett Potter, The Children's Friend (1895).

75. C. D. Shanly, "The Hair, the Moustache, and the Beard," The Treasury of Literature and the Ladies' Treasury, February 1, 1872, 84.

76. Woodforde, The Strange Story of False Hair, 78.

77. "To Wearers of False Hair." The Age, May 1, 1831, 139.

78. G. Renaud, "Waggles's Wig," Judy; or The London Serio-Comic Journal, March 9, 1887. 
79. "The Story of Gaffer Grey," Little Folks, no. 45-48 (1871); C. E. Pearce, "Princess Prettypet," Our Young Folks Weekly Budget of Tales, News, Sketches, Fun, Puzzles, Riddles ofc., November 22, 1873; “The General's Wig," Little Wide-Awake, [1875].

80. The Good-Natured Boy; or, What Came of It. Boys of England: A Journal of Sport, Travel, Fun and Instruction for the Youths of All Nations 28-9, no. 719-36 (1880).

81. Mark Twain, "Man's Place in the Animal World," in Mark Twain's Book of Animals, ed. Shelley Fisher Fishkin (Berkeley: University of California Press, 2009), 124.

82. Mark Twain, Roughing It (London: Penguin, 1988), 386-87.

83. Alfred Edersheim, Shorn to the Wind, The Sunday at Home: A Family Magazine for Sabbath Reading, no. 1014-26 (1873).

84. "None So Blind as Those Who Won't See." Standard, October 5, 1846; "An Injured Frenchwoman." Bristol Mercury, May 17, 1862; "A Glass Eye Expected to See!” Bow Bells 6, no. 131 (1867).

85. "A Glass Eye Expected to See!" 4.

86. "An' they tell me that you've got a glass-eye," Preston Guardian, July 19, $1884,2$.

87. D. B. McKean, "A Wig and a Wooden Leg," Chatterbox, no. 4 (1886): 27; “A Cure for Cannibalism." Pick-Me-Up, no. 37 (1889): 171.

88. "A Cure," 171.

89. Richard F. Patteson, “'King Solomon's Mines': Imperialism and Narrative Structure," The Journal of Narrative Technique 8, no. 2 (1978): 113; Joseph A. Kestner, Masculinities in British Adventure Fiction, 1880-1915 (Burlington: Ashgate, 2010), 67.

90. Kay Heath, Aging by the Book: The Emergence of Midlife in Victorian Britain (Albany: State University of New York Press, 2009), 2.

91. Ibid., 13.

92. Haggard, King, ch. 1. The narrator and protagonist of Haggard's novel, Quatermain, suggests that Good's release from the navy came because "it was impossible that he should be promoted" (ch. 1), alluding, possibly, to the fact that the Captain was not from a prestigious enough family to be promoted further. But such a conclusion does not really explain why he was let go. His deficiencies seem to better explain this decision. Despite his reputation as a "marvellous shot" - established after shooting a moving giraffe calf from 300 yards with his last shot-Quatermain reveals that his companion was in fact a bad shot, hinting that Good may be past his best in terms of military prowess.

93. McKean, "A Wig," 27.

94. "A Cure," 171. 
95. Haggard, King, ch. 1.

96. Ibid.

97. Ibid., ch. 7.

98. Ibid., ch. 1.

99. Poe, "The Man."

100. Bruce Haley, The Healthy Body and Victorian Culture (Cambridge: Harvard University Press, 1978); Erin O'Connor, Raw Material: Producing Pathology in Victorian Culture (Durham: Duke University Press, 2000).

101. Heath, Aging, 13 and 29.

102. Norman Vance, The Sinews of the Spirit: The Ideal of Christian Manliness in Victorian Literature and Religious Thought (Cambridge: Cambridge University Press, 1985), 166; Heath, Aging, 29.

103. Heath, Aging, 28.

104. John Tosh, Manliness and Masculinities in Nineteenth-Century Britain: Essays on Gender, Family, and Empire (Harlow: Pearson Longman, 2005).

105. Haggard, King, ch. 7.

106. Helen Small has shown us that many of these stereotypes have existed since Aristotelean times. Helen Small, The Long Life (Oxford: Oxford University Press, 2007), 52-88.

107. Good's false teeth have been read in various compelling ways, but few have considered the device's comic purpose and how this relates to ageing. Joseph Kestner sees Good's use of dentures as evidence for what Richard F. Patteson's identifies as a key imperial trope: how "heroes establish their influence over natives through a technological device." Merrick Burrow, on the other hand, suggests that Good's teeth are emblematic of "metropolitan artifice," which are perceived as "sacred relics" by the Kukuanaland people. The white men are forced to accept such a position to survive thereby valorizing a masculine adoption of barbarism (a stance that aligns Burrow's work with that of Bradley Deane). Deane observes that "Good's fastidiousness begins to make him a figure of fun," but that is as close as we get in Haggard scholarship to an acknowledgement that Good's teeth are a comic prop representative of a widely used humorous trope. Kestner, Masculinities, 67; Patteson, "King," 113; Merrick Burrow, "The Imperial Souvenir: Things and Masculinities in H. Rider Haggard's King Solomon's Mines and Allan Quatermain," Journal of Victorian Culture 18, no. 1 (2013): 85; Bradley Deane, "Imperial Barbarians: Primitive Masculinity in Lost World Fiction," Victorian Literature and Culture 36, no. 1 (2008): $22 \ln 11$.

108. Haggard, King, ch. 4. 
109. Robert Louis Stevenson, Treasure Island (New York: Harper and Brothers, 1915). As Mavis Reimer writes, "Stevenson's novel prompted H. Rider Haggard to define his novel, King Solomon's Mines (1885), as intended for 'all the big and little boys who read', a readership he saw as distinguishing his work from that of "people who write books for little girls in the school-room." Mavis Reimer, "These Two Irreconcilable Things-Art and Young Girls': The Case of the Girls' School Story," in Girls, Boys, Books, Toys: Gender in Children's Literature and Culture, eds. Beverly Lyon Clark and Margaret R. Higonnet (Baltimore: John Hopkins University Press, 2000), 44.

110. Georgia Haire, “'Does It Really Make You Look Old?’: Dentures, Ageing and Aesthetics in Late Twentieth-Century Britain," workshop paper presented at "Oral Health Inequalities, Oral Hygiene Cultures: Past, Present, Future," University of Kent, June 28, 2018.

\section{REFERENCES}

Bigg, Henry Robert Heather. Artificial Limbs, and the Amputations Which Afford the Most Appropriate Stumps in Civil and Military Surgery. London: Henry Robert Heather Bigg, 1885.

Boyer, George R., and Timothy P. Schmidle. "Poverty among the Elderly in Late Victorian England." The Economic History Review 62, no. 2 (2009): 249-78.

"An Injured Frenchwoman”. The Bristol Mercury, May 17, 1862.

Brontë, Emily. Wuthering Heights. London: John Murray, 1910. Project Gutenberg. Last modified August 28, 2010. https://www.gutenberg.org/ files/768/768-h/768-h.htm.

Brown, Bill. "Thing Theory." Critical Inquiry 28, no. 1 (2001): 1-22.

Burrow, Merrick. "The Imperial Souvenir: Things and Masculinities in H. Rider Haggard's King Solomon's Mines and Allan Quatermain." Journal of Victorian Culture 18, no. 1 (2013): 72-92.

Chandra, Satish, and Shaleen Chandra. Textbook of Community Dentistry. New Delhi: Jaypee Brothers Publishers, 2002.

Chase, Karen. The Victorians and Old Age. Oxford: Oxford University Press, 2009.

-. "Senile' Sexuality." In Interdisciplinary Perspectives on Aging in Nineteenth-Century Culture, edited by Katharina Boehm, Anna Farkas, and Anne-Julia Zwierlein, 132-46. New York: Routledge, 2014.

Chasemore, William Henry Archibald. "Wicklebury's Wig." Judy, January 2, 1878. Collins, Wilkie. Armadale. Oxford: Oxford University Press, 1999.

- The Law and the Lady. Oxford: Oxford University Press, 2008.

- The Black Robe. London: Chatto and Windus, 1910. 
Coogan, Tom, and Rebecca Mallett. "Introduction: Disability, Humour and Comedy." Journal of Literary \& Cultural Disability Studies 7, no. 3 (2013): 247-53.

Copping, Harold. "It Caught His Wig and Jerked It into the Air." Wood-engraved illustration. In Hazelbrake Hollow, by F. Scarlett Potter. The Children's Friend (1895): n.pag.

“A Cure for Cannibalism”. Pick-Me-Up, no. 37 (1889): 171.

Deane, Bradley. "Imperial Barbarians: Primitive Masculinity in Lost World Fiction." Victorian Literature and Culture 36, no. 1 (2008): 205-25.

Dickens, Charles. Dombey and Son. London: Penguin, 2002.

-. Our Mutual Friend. London: Everyman, 2000.

Dickie, Simon. "Hilarity and Pitilessness in the Mid-Eighteenth Century: English Jestbook Humor." Eighteenth-Century Studies 37, no. 1 (2003): 1-22.

Donald, Diana. The Age of Caricature: Satirical Prints in the Reign of George III. New Haven: Yale University Press, 1996.

Edersheim, Alfred. Shorn to the Wind. The Sunday at Home: A Family Magazine for Sabbath Reading, no. 1014-26 (1873): 625-28; 641-45; 657-61; 673-77; 689-93;705-09;721-26;737-40;753-56;769-72;785-89;801-05;817-22.

Eliot, Simon. "The Business of Victorian Publishing." In The Cambridge Companion to the Victorian Novel, edited by Deirdre David, 37-61. Cambridge: Cambridge University Press, 2000.

“A Strange Complaint". Fun, February 18, 1871.

“The General's Wig”. Little Wide-Awake, [1875].

“A Glass Eye Expected to See!” Bow Bells 6, no. 131 (1867): 4.

Goldney, Grace. Marion's Choice. Aunt Judy's Magazine 8, no. 112-14 (1870): n. pag.

The Good-Natured Boy; or, What Came of It. Boys of England: A Journal of Sport, Travel, Fun and Instruction for the Youths of All Nations 28-9, no. 719-36 (1880): 281-83, 313-15, 326-28, 342-44, 374-76; 6-8, 38-40, 54-56, 70-72, 102-4, 118-20, 143-45.

Gullette, Margaret Morganroth. Aged by Culture. Chicago: University of Chicago Press, 2004.

Haggard, H. Rider. King Solomon's Mines. Project Gutenberg. Last modified October 12, 2012. https://www.gutenberg.org/files/2166/2166h/2166-h.htm.

Haire, Georgia. “'Does It Really Make You Look Old?’: Dentures, Ageing and Aesthetics in Late Twentieth-Century Britain." Workshop paper presented at "Oral Health Inequalities, Oral Hygiene Cultures: Past, Present, Future," University of Kent, June 28, 2018.

Haley, Bruce. The Healthy Body and Victorian Culture. Cambridge: Harvard University Press, 1978. 
Hampton, Mark. Visions of the Press in Britain, 1850-1950. Urbana: University of Illinois Press, 2004.

Heath, Kay. Aging by the Book: The Emergence of Midlife in Victorian Britain. Albany: State University of New York Press, 2009.

Hoffman, E. T. A. "The Sandman." In Tales from the German, Comprising Specimens from the Most Celebrated Authors, translated by John Oxenford and C. A. Feiling, n.pag. London: Chapman and Hall 1844. Project Gutenberg. Last modified April 18, 2010. https://www.gutenberg.org/ files/32046/32046-h/32046-h.htm.

Holmes, Martha Stoddard, and Mark Mossman. "Disability in Victorian Sensation Fiction." In A Companion to Sensation Fiction, edited by Pamela K. Gilbert, 493-506. Chichester: Wiley-Blackwell, 2011.

[Horne, Richard H.] "Dust; or Ugliness Redeemed.” Household Words 1, no. 16 (1850): 379-84.

Kestner, Joseph A. Masculinities in British Adventure Fiction, 1880-1915. Burlington: Ashgate, 2010.

"The Rewards of Warfare". Kind Words: A Week-Day Magazine for Boys \& Girls, November 24, 1870.

"Laid up at Greenwich". Judy: or The London Serio-Comic Journal, December 2, 1868.

Leacock, Stephen. Humor: Its Theory and Technique, with Examples and Samples; a Book of Discovery. New York: Dodd, Mead, 1935.

Messrs Mosley's Teeth and Painless Dentistry. Advertisement. Bell's Life in London and Sporting Chronicle 2, no. 365 (1867): 3.

Mitchell, David T., and Sharon L. Snyder. Narrative Prosthesis: Disability and the Dependencies of Discourse. Ann Arbor: University of Michigan Press, 2000.

"Modern Sonnet. To an Old Wig". In The Spirit of the Public Journals for 1802, vol. 6, 112-13. London: James Ridgway, 1803.

Morreall, John. "Humour and the Conduct of Politics." In Beyond a Joke: The Limits of Humour, edited by Michael Pickering and Sharon Lockyer, 63-78. Basingstoke: Palgrave, 2005.

Mr. H. Lyon and Mr. Tindall, Dentists. Advertisement. Ipswich Journal, January 2, 1878.

“Mr. Sagtooth's First Appearance”. Funny Folks 17, no. 853 (1891): 108-109.

Mr. Scott, Surgeon and Mechanical Dentist. Advertisement. Bell's Life in London and Sporting Chronicle 417 (1830): 2.

"Mr. Wegg and His Class". All the Year Round 18, no. 441 (1877): 250-53.

Multiple classified advertisements. Lady's Newspaper, no. 599 (1858): 399.

"The New Wig Club". Punch, May 26, 1855.

Nicholson, Bob. "Jonathan's Jokes." Media History 18, no. 1 (2012): 33-49. 
Niles, Lisa. “Owning 'the Dreadful Truth'; or, Is Thirty-Five Too Old?: Age and the Marriageable Body in Wilkie Collins's Armadale." Nineteenth-Century Literature 65, no. 1 (2010): 65-92.

O'Connor, Erin. Raw Material: Producing Pathology in Victorian Culture. Durham: Duke University Press, 2000.

Ofek, Galia. Representations of Hair in Victorian Literature and Culture. Aldershot: Ashgate, 2009.

"The Old Man and His Grey Wig". The Age, February 12, 1832.

Patteson, Richard F. “'King Solomon's Mines': Imperialism and Narrative Structure." The Journal of Narrative Technique 8, no. 2 (1978): 112-23.

Pearce, C. E. "Princess Prettypet." Our Young Folks Weekly Budget of Tales, News, Sketches, Fun, Puzzles, Riddles \&c., November 22, 1873.

Pearl, Sharrona. About Faces: Physiognomy in Nineteenth-Century Britain. Cambridge: Harvard University Press, 2010.

Poe, Edgar Allan. "The Man That Was Used Up: A Tale of the Late Bugaboo and Kickapoo Campaign." In The Works of the Late Edgar Allan Poe, by Edgar Allan Poe, vol. 4, 315-25. New York: Blakeman \& Mason, 1859.

—. "The Spectacles." In Prose Tales (Second Series) Arthur Gordon Pym, by Edgard Allan Poe, 161-98. Boston: Dana Estes, 1884.

“An' they tell me that you've got a glass-eye". Preston Guardian, July 19, 1884.

Rauser, Amelia F. "Hair, Authenticity, and the Self-Made Macaroni." EighteenthCentury Studies 38, no. 1 (2004): 101-17.

Reimer, Mavis. "'These Two Irreconcilable Things-Art and Young Girls': The Case of the Girls' School Story." In Girls, Boys, Books, Toys: Gender in Children's Literature and Culture, edited by Beverly Lyon Clark and Margaret R. Higonnet, 40-52. Baltimore: John Hopkins University Press, 2000.

Renaud, G. "Waggles's Wig." Judy; or The London Serio-Comic Journal, March 9, 1887.

Richardson, Henry S. Greenwich: Its History, Antiquities, Improvements, and Public Buildings. Greenwich: Harriet Richardson, 1834.

Rowland, Alexander. The Human Hair, Popularly and Physiologically Considered with Special Reference to Its Preservation, Improvement and Adornment, and the Various Modes of Its Decoration in All Countries. London: Piper, Brothers \& Co., 1853.

[Rymer, James Malcom]. Varney the Vampire; or, The Feast of Blood. Project Gutenberg. Last modified October 4, 2011. http://www.gutenberg.org/ files/14833/14833-h/14833-h.htm.

Senf, Carol A. The Vampire in Nineteenth Century English Literature. Madison: University of Wisconsin Press, 2013.

Shakespeare, Tom. "Joking a Part.” Body \& Society 5, no. 4 (1999): 47-52.

Shanly, C. D. "The Hair, the Moustache, and the Beard." The Treasury of Literature and the Ladies' Treasury, February 1, 1872. 
Small, Helen. The Long Life. Oxford: Oxford University Press, 2007.

Sontag, Susan. "The Double Standard of Aging." In Psychology of Women: Behavior in a Biosocial Context, edited by Juanita H. Williams, 462-78. 3rd ed. London: Norton, 1987.

"None So Blind as Those Who Won't See". The Standard, October 5, 1846.

Stevenson, Robert Louis. Treasure Island. New York: Harper and Brothers, 1915. "The Story of Gaffer Grey". Little Folks, no. 45-48 (1871): 292-93; 314-15; $322-23 ; 338-39$.

Swift, Jonathan. “A Beautiful Young Nymph Going to Bed.” Poetry Foundation. Accessed July 2, 2018. https://www.poetryfoundation.org/ poems $/ 50580 /$ a-beautiful-young-nymph-going-to-bed.

Thackeray, William Makepeace. The Virginians. 2 vols. London: Bradbury and Evans, 1858-1859.

Thane, Pat. Old Age in English History: Past Experiences, Present Issues. Oxford: Oxford University Press, 2002.

-. "Epilogue." In Interdisciplinary Perspectives on Aging in NineteenthCentury Culture, edited by Anne-Julia Zwierlein, Katharina Boehm, and Anna Farkas, 232-46. New York: Routledge, 2014.

Thomas Elliott, Hair Cutter, Hair Grower, Wig Maker, and Perfumer. Advertisement. [c.1860]. EPH 160B. Hair care box 9. Wellcome Library, London.

"Thrift, or Nothing Is Useless". Chambers's Edinburgh Journal 1, no. 38 (1844): 191-92.

Tosh, John. Manliness and Masculinities in Nineteenth-Century Britain: Essays on Gender, Family, and Empire. Harlow: Pearson Longman, 2005.

“To Wearers of False Hair". The Age, May 1, 1831.

Trollope, Anthony. The Way We Live Now. London: Penguin, 1994.

Twain, Mark. Roughing It. London: Penguin, 1988.

—. "Man's Place in the Animal World." In Mark Twain's Book of Animals, edited by Shelley Fisher Fishkin, 117-25. Berkeley: University of California Press, 2009.

Vance, Norman. The Sinews of the Spirit: The Ideal of Christian Manliness in Victorian Literature and Religious Thought. Cambridge: Cambridge University Press, 1985.

Woodforde, John. The Strange Story of False Teeth. London: Routledge and Kegan Paul, 1968.

- The Strange Story of False Hair. London: Routledge and Kegan Paul, 1971.

Zwierlein, Anne-Julia, Katharina Boehm, and Anna Farkas, eds. Interdisciplinary Perspectives on Aging in Nineteenth-Century Culture. New York: Routledge, 2014. 
Open Access This chapter is licensed under the terms of the Creative Commons Attribution 4.0 International License (http://creativecommons.org/licenses/ by $/ 4.0 /$ ), which permits use, sharing, adaptation, distribution and reproduction in any medium or format, as long as you give appropriate credit to the original author(s) and the source, provide a link to the Creative Commons licence and indicate if changes were made.

The images or other third party material in this chapter are included in the chapter's Creative Commons licence, unless indicated otherwise in a credit line to the material. If material is not included in the chapter's Creative Commons licence and your intended use is not permitted by statutory regulation or exceeds the permitted use, you will need to obtain permission directly from the copyright holder. 